\title{
THE IMPACT OF SUPER VISA ON CHINESE IMMIGRANT FAMILIES' SETTLEMENT IN CANADA
}

\author{
by \\ Ivy Li, BA, UOIT, 2016 \\ LLB, Shandong University, 1991 \\ LLM, Renmin University, 2001
}

\author{
A Major Research Paper \\ presented to Ryerson University
}

in partial fulfillment of the requirements for the degree of

Master of Arts

in the program of

Immigration and Settlement Studies

Toronto, Ontario, Canada, 2017

C Ivy Li 2017 


\section{AUTHOR'S DECLARATION FOR ELECTRONIC SUBMISSION OF A MAJOR RESEARCH PAPER (MRP)}

I hereby declare that I am the sole author of this MRP. This is a true copy of the MRP, including any required final revisions. I authorize Ryerson University to lend this MRP to other institutions or individuals for the purpose of scholarly research. I further authorize Ryerson University to reproduce this MRP by photocopying or by other means, in total or in part, at the request of other institutions or individuals for the purpose of scholarly research. I understand that my MRP may be made electronically available to the public. 


\title{
THE IMPACT OF SUPER VISA ON CHINESE IMMIGRANT FAMILIES' SETTLEMENT IN CANADA
}

\author{
Ivy $\mathrm{Li}$ \\ Master of Arts 2017 \\ Immigration and Settlement Studies \\ Ryerson University
}

\begin{abstract}
In November 2011, Citizenship and Immigration Canada (CIC) announced a new Super Visa program as a successful alternative for family reunification. Scholars have criticized that Super Visa just adds more barriers to family reunification. Through qualitative interviews with immigrants who have sponsored their parents as well as parents who have come to Canada on Super Visa, this study aims to better understand the experiences of immigrant families, and make their voices heard. The key findings of this study indicate that Super Visa is helpful for family reunification especially for those whose regular visa applications are not successful. However, due to its limitations, Super Visa cannot replace the immigration sponsoring program for parents/grandparents. Some recommendations such as requesting fewer documents and information from parents and making the application easier for them, more flexible and affordable options for purchasing private medical insurance are made in order to improve the program to better serve immigrant families.
\end{abstract}

Keywords: Canadian immigration policy, Super Visa program, parents/grandparents immigration, family reunification, experience of parent(s) with Super Visa, qualitative semi-structured interviews 


\section{ACKNOWLEDGEMENTS}

I would like to thank my husband, Jeff, who always supports me in furthering my

education. I also want to thank my professors and classmates who have offered me with interesting and inspiring learning experiences. In particular, I want to express my sincere appreciation to my supervisor, Dr. Sepali Guruge, who always encourages me and has spent so much time and effort in helping me complete my MRP.

Thank you all with my whole heart! 
Author's Declaration .................................................................................................... ii

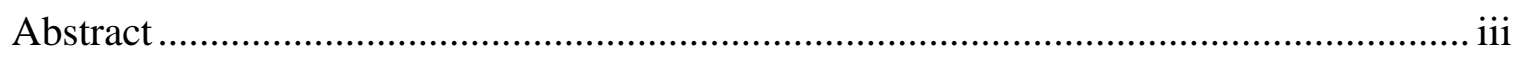

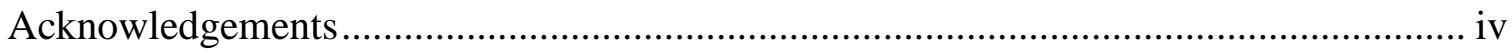

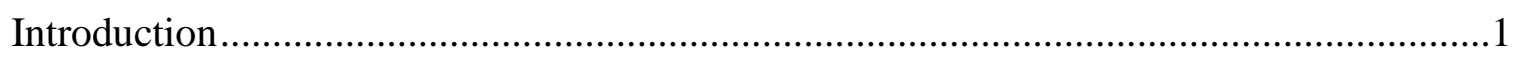

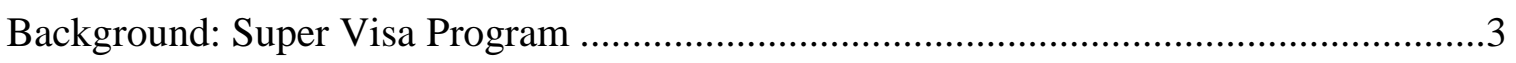

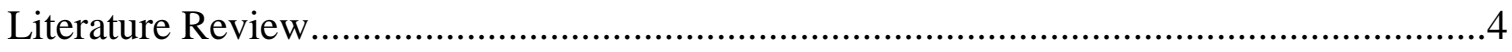

Methods: Research Problems and Questions ........................................................... 15

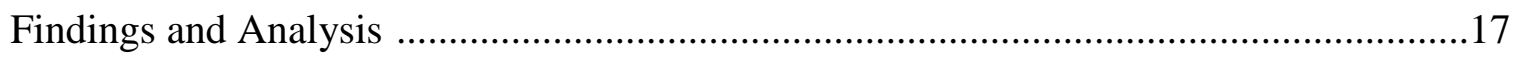

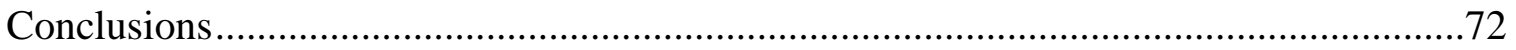

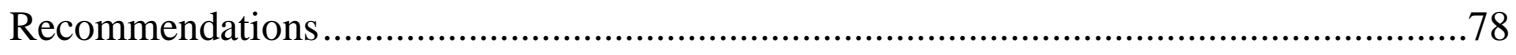

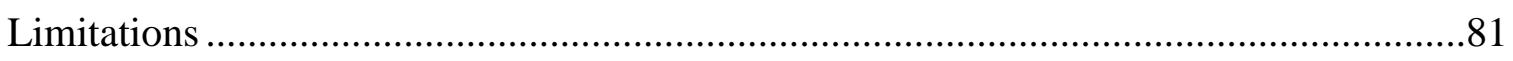

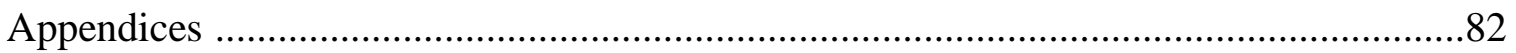
A. Interview Questions
B. Low Income Cut-Off Table (IRCC)

References 


\section{INTRODUCTION}

In November 2011, the CIC decided to temporarily stop the parents/grandparents sponsorship program for two years (2012 and 2013), and simultaneously, announced a new multiple-entry Super Visa program that allows parents/grandparents to visit their children/grandchildren for up to two years at a time (CIC, 2011). Immigration sponsorship application for parents/grandparents was reopened in January 2014 with a cap of 5000 applications, and the new policy has extended sponsors' undertakings for their parents/grandparents such as food, clothing, shelter, fuel, household supplies and other personal needs from 10 years to 20 years, as well as required sponsors to meet a minimum income requirement for consecutively three years (previously for 1 year) (CIC, 2014).

The Federal Government has argued that the policy change was made to reduce the large application backlog and extensive waiting time, and the new Super Visa initiative is intended to facilitate family reunification (CIC, 2011). After two years of implementation of Super Visa, the government has claimed that this alternative program is successful, because the processing time for Super Visa is on average eight weeks rather than eight years for parents/grandparents sponsorship immigration program, and it allows the parents/grandparents stay longer in Canada compared to regular visitor visa (CIC, 2013).

A literature review indicates there is a mismatch between Super Visa policy's intention and its actual outcomes as well as its added barriers to family reunification. Some scholars argue that although Super Visa can bring parents/grandparents to Canada, it is not a viable alternative for family reunification due to its prohibitive costs and its temporary nature which prevents family from making meaningful long-term plans as 
integrated family units (Bragg, 2014, Neborak, 2014). In addition, the identity of parents /grandparents in Canada is recognized as undesirable immigrants by government and popular discourse and as a big burden on the welfare and social service systems (Collacott, 2013, Bragg \& Wong, 2016). Some scholars argue that contributions to families in Canada by parents/grandparents have been greatly devalued and the identity imposed on parents/grandparents not only systemically undermines the value of family reunification held in Canada's immigration history, but also reinforces the racial stratification in Canadian society (Bragg, 2014, Neborak, 2014, Bragg \& Wong 2016).

This MRP will explore the experiences of immigrants who have brought parent(s) to come to Canada and their parent(s) who have come to Canada on a Super Visa. It will have two main parts. In the first part, I will mainly set the context for the discussion of family reunification under Super Visa. I will first give an explanation of the Super Visa program, and provide a brief review of literature on the main reasons and underlying ideologies of the policy change of parents/grandparents immigration sponsorship program and the initiative of Super Visa by the government, as well as the main discourses with regard to the identity of parents/grandparents and their roles in immigrant families' settlement in Canada. I will examine the identity of parents/grandparents recognized by the state and the popular discourse, and provide a beginning analysis of its impact on immigrant families' settlement, integration, and belonging. In the second part, I will explain my study design, and present my main findings with regard to the experiences of immigrant families with Super Visa, and compare my findings with those of other studies. 
At the end of this MRP, I will provide my recommendations on how to improve the Super Visa program, so it can better serve the immigrant families and help their settlement in Canada.

\section{PART I:}

\section{A. BACKGROUND: WHAT IS SUPER VISA?}

Super Visa is a temporary visitor visa specifically for parents/grandparents whose adult child/grandchild is a Canadian citizen or permanent resident. It is part of the "Phase I of the Action Plan for Faster Family Reunification” issued by the Federal Government (CIC, 2011). It was announced by CIC in November 2011 and took effect on December 1, 2011(CIC, 2011).

Different from multiple-entry regular visitor visa, it allows the parents/grandparents to stay in Canada for up to 2 years rather than 6 months at a time after entering Canada. Similar to the regular multiple-entry visitor visa, Super Visa also allows multiple-entry valid for up to 10 years but cannot exceed the validation date of passport. For example, if an applicant's passport will be expired in 6 years, then they will be granted a Super Visa for only 6 years rather than 10 years.

In contrast to the regular multiple-entry visitor visa, in order to apply for a Super Visa, the adult immigrant children/grandchildren must meet a minimum family income requirement that is above the Low-Income Cut-off released by government each year (IRCC, 2017). In addition, they must purchase $\$ 100,000$ private medical insurance coverage for at least one year for each parent/grandparent, and provide a written statement of financial support during their stay. At the same time, parent/grandparent must pass an immigration medical examination, and meet all other requirements in general (IRCC, 2017). 


\section{B. LITERATURE REVIEW}

\section{Reasons and Ideologies Underlying the Immigration Policy Change and Super Visa Design}

Allowing immigrant children to sponsor their parents to immigrate to Canada has been a cornerstone commitment promised by the Federal Government to newcomers (Bragg, 2014, p.1). The emphasis on value of family reunification was manifested in the earlier Canadian immigration system and policy design. For example, admitting immigrants with relatives was outlined in 1908 immigration policy, and the Immigration Act of 1910 allowed immigrants bringing their relatives not only including wives and children, but also parents, brothers and sisters to Canada (Neborack, 2014, p.3). Although there was a variation of family immigration policy due to the great discretion power of the cabinet, the family immigration policy remained from the early 1900 s to the 1970 s, and the importance of family reunification was still a strong feature of immigration policy (Neborack, 2014, p.4).

In the 1980s, on one hand, Canada experienced an economic downturn and the annual admission of immigrants reached the lowest number in 1985, on the other hand, the 1976 Immigration Act outlined the humanitarian international obligation of Canada, the increasing influx of refugee during 1980s led to the hot debates among parliament and the public (Neborack, 2014, p.5). The situation required a proper balance between economic immigrants, family class and refugee entrance (Neborack, 2014, p.5). In 1990s, with more new immigrants coming from Asia and the Middle East, the new immigrants were blamed by the popular discourse for the socioeconomic problems such as high unemployment rate and government spending. The immigration debate not only focused 
on who should be defined as ideal immigrants, but also on how to enhance labour market after the new immigrants came to Canada (Neborack, 2014, p.5). Consequently, Canada has shifted its immigration policy to economic-focus since 1990s (Arat-Koc, 1999, Bragg \& Wong, 2016).

The ideology of neo-liberalism posits the economy under global competition and engenders the construction of "model citizen" (Abu-Laban \& Gabriel, 2002, p.96). The high-skilled economic immigrants are seen as representing "self-sufficient, masculine and contributing to the nation, while family-class immigrants are constructed as feminine, dependent, and noncontributing” (Bragg \& Wong 2016, p.48). Given that the older adults in general have lower labour market participation and higher need for public health services, both the government and popular discourse regard elderly parents/grandparents as an economic cost to Canada and a burden on the social service system, and argue for limiting their immigration (Collacott, 2013, Bragg \& Wong, 2016).

In addition, neoliberal values of self-sufficiency, self-reliance and independence justify the reduction of state welfare and the shift from state responsibility to individual responsibility, thus provide a platform to connect the immigration policy with state's welfare system (Arat-Koc, 1999). Extending children's /grandchildren's sponsorship obligation from 10 years to 20 years, and putting the entire medical and other care burden of elderly parents/grandparents solely on the shoulders of immigrant family for a Super Visa are good examples.

Moreover, human capital theory drawn from neo-classical economics, regards individual's education as an "investment" which can provide a "return" in the labor market (Gabriel, 2006, p.164). The idea that the more skills and formal education an individual has, the more likely he/she will succeed in the labour market and contribute to 
society results in the devaluation of non-economic contributions such as unpaid childcare and other household work by family members (Bragg \& Wong, 2016, p.50). Solely focusing on individual economic outcome, human-capital discourse not only ignores the relation between immigrants' economic establishment and their social and emotional needs, but also denies the values of the support from family members such as parents/grandparents (Bragg \& Wong, 2016, p.55), thus contributing to more stringent policy changes.

\section{Critique on Super Visa}

\section{$\underline{\text { Super Visa is Only for the Rich }}$}

Super Visa is criticized by some scholars as being only for the rich because many families cannot meet the income threshold or cannot afford the high cost of mandatory health premium (Keung, 2011). For example, if an immigrant family have four people in their family (husband, wife, and two children), and want to apply for Super Visa for husband's parents, their family income must be more than $\$ 58473$ for a family of six (IRCC, 2017); if they also want to apply for Super Visa for the wife's parents simultaneously or while the husband's parents are still staying with them in Canada, they must meet the minimum income requirement for a family of eight people (i.e., \$71929) (IRCC, 2017). In order to prove their family income, the family must provide the Notice

of Assessment issued by Canada Revenue Agency (CRA) and employment confirmation letter signed by employer. Many immigrant families cannot meet the minimum income requirement, especially those newcomers who are from the Global South and participate in the second/peripheral labour market.

The expensive medical insurance premium is criticized as another great barrier. For example, if an elderly parent is 75 years old, the cost of the mandatory insurance will 
be almost $\$ 4000$ or even more depending on different insurance providers. For the application for one parent, the legal fee will be around $\$ 500-\$ 1200$, the medical examination fee will be $\$ 400-\$ 500$, and the application fee is $\$ 100$, as well as other fees such as translation and notary fees will be around $\$ 100-\$ 300$, the total cost of a Super Visa will be around $\$ 5000-\$ 6000$. As such, some scholars argue that Super Visa is a more costly option for family reunification than family sponsorship.

Due to the prohibitive costs, some families have to borrow money in order to apply for a Super Visa for their parents (Bragg \& Wong, 2016, p.54). Some families prefer a six-month regular visa which is more economically viable although they know that the Super Visa allows a longer stay of their parents (Bragg, 2014, p.9). Families that cannot afford the cost of childcare, and need two incomes to survive, often have to send their children back to their home country to be raised by their parents or other extended families if they cannot obtain a regular or super visa for their parents (Zhou, 2013, p.283). Hence, some researchers conclude that Super Visa fails to meet the needs of many low and middle-income immigrant families who are usually with the dire need for parental support (Bragg \& Wong, 2016).

\section{Challenges and Difficulties of Application Process}

Although government is proud of the efficiency of the process of Super Visa (CIC, 2013), to many immigrant families, the application of a Super Visa is a complicated, time consuming and involves a frustrating process. Ilyan Ferrer's case study (2015) on a couple who are immigrants from the Philippines shows that the application process involves the CIC, the Canadian embassy in the Philippines, Visa Application Center (VAC) which is the contracted service provider with CIC, and the designated courier service provider for the delivery of the paper application. As applicants, they have to 
cooperate with the bureaucratized relationship among all these authorities and service providers.

In addition, families who choose to submit a paper application rather than an online application must use a VAC usually located in only some countries and/or only in several big cities in such countries. Many applicants have to travel far to submit their applications if they choose to submit in person rather than by mail to VAC. Moreover, many applicants have to travel to have medical examination because physicians designated by CIC/IRCC usually only are available in a handful of big cities. These practical difficulties and extra costs add more barriers to access to Super Visa for the immigrant families, especially those from the Global South whose parents often have no internet access and/ or may live far away from big cities.

\section{Super Visa Is Not a Successful Alternative for Family Reunification}

Super Visa is out of the reach of many low and even middle-income families due to the income threshold and/or its prohibitive cost. To some immigrant families, the Super Visa only is "the illusion of family reunification" (Bragg, 2014, p.11). Considering that its requirement is based on the immigrants' socio-economic status and the added barriers faced by the immigrant families from the Global South, some scholars conclude that Super Visa is "a stratified solution that only serves to further reinforce financial and racial barriers" (Neborak, 2014, p. 10).

Moreover, some researchers believe that Super Visa cannot be regarded as a viable alternative for family reunification due to its temporary nature (Bragg, 2014, p.9) The government claims that Super Visa intends to help the family reunification, but the parents/grandparents have to leave Canada after a maximum stay of 2 years, thus the 
government categorizes the elderly parents/grandparents as mere temporary visitors rather than family members.

In addition, due to the temporary status, parents/grandparents are ineligible for state-provided services and entitlement, and all medical and other caring responsibilities are on the shoulders of immigrant family and/or their parents/grandparents (Ferrer, 2015). Moreover, the temporary status of parents/grandparents with Super Visa prevents family from making meaningful long-term plan as an integrated family unit (Bragg, 2014, p.9). Therefore, Super Visa fails to provide a long-term solution to family separation (Bragg, 2014, p.11).

Furthermore, the CIC reports that there is an overall high approval rates for Super Visa, however, scholars argue that there is a much lower approval rate than U.S. and Europe from the Global South such as Africa, Asia, and the Middle East which means that racialized newcomers get much less benefits from the Super Visa (Neborak, 2014, p. 11, Bragg, 2014). This further demonstrates that Super Visa reinforces the racial stratification.

\section{Identity of Parent/Grandparent in the Eyes of Government and Popular}

\section{Discourse}

Government has absolute discretion on the entry of foreign-born people into Canada. Over the past 20 years, there has been a great increase of admission of economic class immigrants and a sharp decline in family and refugee admission, and it is obvious that the selection criteria are more and more based on the maximizing economic benefits to Canada (Siemiatycki, 2015, p.107). This selection approach focuses on the welleducated and economic elites of other countries as "social eugenics" because it 
distinguishes some immigrants as desirable and others as undesirable according to their social status (Siemiatycki, 2015, p.107).

Under this approach, the parents/grandparents who are beyond their employment years are deemed of non-contribution to economy and as incurring more health care cost, thus as undesirable immigrants. This is reflected in the lengthy processing time for sponsoring parents/grandparents (i.e., on average 8 years), and the government is reluctant to grant them the permanent resident status which will enable them for the eligibility of public health care and other public services (Siemiatycki, 2015, p.108).

The minister of CIC openly states that the country's generosity has to be limited, and the state must consider its economic needs and fiscal capacity (Bragg \& Wong, 2016, p. 49). Conservative think tank Fraser Institution blames the family class immigration results in "chain migration" (Collacott, 2013, p.6) which brings into Canada undesired elderly parent/grandparent immigrants "who were unskilled, often nearly illiterate, and not likely to make a positive economic contribution to Canada" (Collacott, 2013, p.7). Fraser Institution also points out that the parents/grandparents coming to Canada from the four principal source countries (India, China, Philippines and Sri Lanka) are doing so for Canada's better senior benefits, health care and social services (Collacott, 2013, p.6). Fraser Institution argues that a sponsored parent/grandparent will receive Old Age Security, Guaranteed Income Supplement payments and other government transfers which would amount to $\$ 152,880$, and plus an estimated $\$ 160,000$ health care cost, a total of $\$ 312,880$ if lives in Canada from the age of 65 to 85 , which is putting strain to a health care and pension system already in crisis (Collacott, 2013, p.13).

In summary, in the eyes of the state and the popular discourse, elderly parents/grandparents cannot contribute to Canada, and are big burdens on the Canadian 
society. Although their families have been living in Canada permanently and pay tax to government, parents/grandparents on Super Visa are perceived as unwelcomed "others" who try to come to Canada to take advantage of the social resources which only belong to Canadians.

\section{Impact of the Negative Portraying of Parent/Grandparent's Identity}

The negative portraying of the identity of parent/grandparent and the constraint of the family reunification with elderly parents/grandparents by the state has a great negative impact on the lives of immigrant families.

Firstly, it has a negative impact on the settlement of immigrant family, especially women and children (Bragg \& Wong, 2016, p.52). Without emotional and practical support from extended relatives, especially parents, immigrant women with children often face great difficulties to balance professional, social and domestic lives (Bragg \& Wong, 2016, p.53).

Childcare fees are typically the second highest cost (after housing) in Canada and the prohibitive cost of childcare makes many immigrant women leave their jobs and stay at home to take care of their children, and some may never return to labour market (Bragg \& Wong 2016, p.53). For some families, the need for two incomes to survive and the prohibitive cost of childcare make them send their children back to their home country to be raised by extended families (Zhou, 2013, p.283). Some families have to borrow money to cover the cost for the Super Visa, so that their parent can come to help them for the childcare (Bragg \& Wong, 2016, p.54). Research findings of Zhou (2013) and Wong (2016) confirm that the help from elderly parents/grandparents are crucial to the economic survival and settlement of the newcomer families in Canada especially those with children. 
Secondly, it increases the social and economic costs on the transnational family (Bragg \& Wong, 2016, p.55). "Home may be geographically relocated, family as a sociocultural and economic unit remains connected" (Zhou, 2013, p.3). While adult children immigrate to and settle in another country, transnational family is constituted through exchange of care and support between the three generations. Immigrant adult children still have to take care of their elderly parents in their home country via financial support, visiting, phone calls etc.; similarly, the elderly parents are needed by their adult children for childcare, emotional support, and/or financial support such as down-payment for the house, grandchildren's tuition and other family expenses (Zhou, 2013, Stephen, 2013, Bragg \& Wong, 2016). The separation of family put incredible stress and anxiety on adult children in Canada who feel accountable to elderly parents in home country. For example, if parents in home country are sick, the adult children worry about them and feel obligated to fly back to take care of them, which along with economic cost, greatly disrupt adult children's work and their family's life (Bragg \& Wong, 2016. P. 56). In addition, the immigrant adult children have concerns about their children growing up without the support and love of grandparents. Some may have had children before moving to Canada and their elderly parents have lived together with them and helped to take care of the grandchildren. Having grown up with a grandparent who is often regarded as "a third parent", the grandchildren feel miserable without them (Bragg \& Wong, 2016. p.56).

Thirdly, restrictions to family reunification disproportionately affect racialized immigrants from the Global South who are the most reliant on the parents/grandparents sponsorship program, and not being able to bring their relatives to Canada reinforce their feeling of exclusion in Canada (Bragg \& Wong, 2016, p.59). For example, a participant 
of Bragg and Wong's study reported that immigrants are wanted only because they pay taxes; their parents are not welcomed to Canada to live with them (2016, p.59). One immigrant from Philippines said that she still feels that she is only a contract worker or a visitor in Canada because her parents are not in Canada (Bragg \& Wong, 2016, p. 59).

Bragg and Wong's (2016) research demonstrates that economic and labour market integration is only one dimension of integration, social and cultural dimensions are also important. Reducing immigrants to only their contribution to labour market and ignoring their emotional and social needs as people with family equates immigrants to "outsiders", and can prolong and exacerbate their integration process in Canada. Prohibiting or limiting immigrants from sponsoring their parents/grandparents is a major barrier to immigrants' full integration (Bragg \& Wong, 2016, pp.59-60). The restrictions to family reunification also affect the ability for Canada to grow as an inclusive and diverse country, and make visible the gap between those who are born in Canada and who are not reinforcing the racial hierarchy (Bragg, 2014, p.27).

\section{The Identity of Parent/Grandparent in the Eyes of Immigrant Family}

Besides ideology and value differences, cultural differences between the West and the East contribute to the portraying of the identity of elderly parents/grandparents.

It is the culture of most eastern countries that when children are young, parents take care of children, and when parents get old, children take care of parents (Bragg \& Wong, 2016. P. 56). For example, Chinese "traditional" norm of "filial piety" regards that it is children's responsibility to take care of their elderly parents (Zhou, 2013, p. 293). Caring for the grandchildren by elderly parents is also a traditional family obligation (Zhou, 2013, p. 287). These expectations and responsibilities are very different from the 
Western culture where the young people leave home and are expected to leave their parents once they reach adult age and there are no strict care obligations between them. Eastern cultural values regard grandparents as passing cultural values to third generation, and help their integration, belonging, and identity construction (Bragg \& Wong, 2016, Zhou, 2013, Stephen, 2013).

Responding to the human capital measurement which ignores the unpaid caregiving of elderly parents, one participant of Zhou's research argues that her parents' contribution should be viewed as the money she brings to home and the more taxes her family paid to government (Zhou, 2013, p.289). The research findings of scholars demonstrate the importance and crucial role of elderly parents/grandparents in economic and social integration of immigration families including both first and second generations.

Bragg and Wong's research finds that having a grandparent in the family not only can provide stability and develop sense of home and belonging for racialized youth, and mitigate the challenges such as discrimination, and language learning, but also can facilitate their construction of identity and sense of descent and origin, as well as promote culture understanding and heritage, and mother tongue learning (2016. p. 57-58). Neborak (2013) points out that grandparents play an important role not only in understanding cultural difference, dealing with racialized interactions, negotiating of ethnic identity, but also in developing ethnic identity and generating social rich multiculturalism rather than a racialized dominant national identity (Neborak, 2013, p.17).

In summary, researchers argue that immigration policy changes and the Super Visa program design which are based on the neoliberalism and human capital theory regard elderly parents/grandparents not only as undesirable immigrants who cannot contribute to the economy but also a big burden on the health and social services system. 
This attribution of identity results in the sharp drop of acceptance of immigrants under family class especially parents/grandparents, as well as the failure of Super Visa as a viable alternative to family reunification with them. The identity imposed on immigrant's parents/grandparents by the government and popular discourse devalues or undervalues the social and emotional support of parents/grandparents and their crucial role in the settlement of their immigrant children and grandchildren. The Super Visa program fails to meet the needs of the low and middle-income immigrant families who are mainly from the Global South, as well as with the dire need for parental support. It not only further marginalizes the vulnerable population, but also reinforces the cycle of poverty.

\section{PART II}

\section{METHOD OF STUDY}

\section{$\underline{\text { Research Problem and Research Questions }}$}

A literature review indicates that there is a mismatch between Super Visa policy's intention and its actual outcomes. While the Federal Government claims that Super Visa is a viable alternative of parents/grandparents immigration sponsoring program, scholars find that Super Visa adds more barriers to family reunification.

My study will explore the real experiences of immigrants and their parents in answering the question: What are the experiences of the immigrant families with Super Visa?

\section{Research Method}

Using a qualitative research design, I will explore the experiences of Chinese immigrant families with Super Visa through semi-structured conversational interviews. I will interview immigrant children who have obtained a Super Visa for their parents, as 
well as their parents. Only those whose parents have come to Canada on a Super Visa will be included.

I received the REB approval (REB 2017-164) to conduct the study on June 27, 2017. Upon the approval, I started the recruitment right away. I contacted friends that I knew who had applied for a Super Visa for their parents, and also asked them to recommend their friends who had applied for Super Visa for parents. I also contacted my previous Super Visa applicant clients. I only had recruited clients as participants who did not have immigration-related applications or any other legal services with us. I sent the Recruitment Letter, Letter to Elderly Parents, and Consent Agreement which were both in English and Chinese to the participants by email. The interviews were conducted in Mandarin.

I planned to recruit 10-15 families, and interview 10-20 adult immigrants and 1020 senior parents. Unfortunately, several families who would like to participate in the research were not available during the required time period. Among the final nineteen (19) participants who were available, twelve (12) were immigrant children, seven (7) were parents. Among those who are parents, only one were available for an in-person interview; the other six (6) participated by answering the questions in writing.

The nineteen (19) participants are from 9 families. Nine (9) are males and among them six (6) are immigrants and three (3) are parents; ten (10) are females and among them six (6) are immigrants and four (4) are parents. Among the 19 participants, two (2) are single immigrants, and all others (immigrant and parent) are married.

Among the immigrants, eight (8) immigrated to Canada more than ten years ago, three (3) more than five years ago, and one (1) less than five years. One (1) family has 
three children, three (3) families have one child, three (3) families have two children, and two (2) families do not have a child. All the children are 15 years old of age or younger.

\section{Data/Topics of Discussion and Analysis Method}

Both immigrants and their participating parents were asked seven to ten questions.

Questions were used to code and thematically organize the data. The following topics were discussed with the participants and the method of coding was employed for the analysis.

1. Reasons for applying for Super Visa for parent(s)

2. Experiences of Application

Challenges and difficulties

3. Discussion regarding the three specific requirements for a Super Visa

Income requirement; purchasing private medical insurance; taking medical examination

4. Super Visa or Regular Multiple-Entry Visa?

5. Impact of parents' stay on immigrant children's life
A. Benefits and Challenges
B. Value of parents to Canada or only burden?
C. Roles of your parent (s) in your children's education and inheritance of

culture

6. Parents' experiences in Canada

7. Super Visa, Immigration and Family Reunification

8. How to improve Super Visa program?

2. FINDINGS AND ANALYSIS

1) Reasons for applying for Super Visa for parent(s) 
According to the Federal Government, the two years of stay in Canada is the privilege and the main attraction of Super Visa. However, all of the participants of my study stated that the main reason for choosing Super Visa was the easier application process and the better approval. For some participants, the 2-year time period was the second main consideration. For others, this was not a concern. Their only concern was to get approved and bring their parents to Canada as soon as possible.

Participants (husband and wife) from a family told me that they had applied four times for regular visitor visas for the wife's parents every year between 2008 and 2012 without success. However, when they applied for the husband's parents, the applications were approved even though both sides of parents have similar background and financial situation. This situation had frustrated the family for quite a long time. The wife had received a diagnosis of mild depression while she was pregnant because of the refusals of her parents' applications. They needed her parents to come to Canada to help her with support and caregiving to her and their newborn. Her parents were saddened that they could not help their children at time of need. Her husband was angry and had written three letters to the office of Jason Kenney, the then CIC minister.

When they applied for Super Visa for the wife's parents in 2013, the application was approved. The husband emphasized that the "certainty" of the policy is what is important to him. He points out that "we do not complain about the requirements, but government must clearly tell me what their requirement is."

Similar to this perspective, another participant mentioned that she had applied for regular visa for her parents for three times without success. She believes that the reason of refusal is that when she first applied for visa for her parents, they were less than 60 years old, so CIC suspected that they might work illegally and might not leave when the 
visa expired. Another reason is that the financial situation of both her parents and her was not good at that time. Later, she learned that Super Visa was much easier. Application for a Super Visa only considers children's financial situation and there is no requirement for parents' side. So, when they met the income requirement, they applied for Super Visa for her parents and the application was approved. With this experience, they also choose to apply for Super Visa for husband's parents although his parents only plan to stay in Canada for about two months. The application was approved.

Another participant stated that she applied for a regular visa for her parents several times and all were refused based on the reason that her parents did not meet the requirement. When the family applied for a Super Visa, the application was approved.

Another participant's decision on the application for a Super Visa for his mother demonstrates the same consideration. He is single and was ill last year, and needed his parents to come to Canada to take care of him. When he prepared the application, he found that regular visa requires parent to provide proof of income, property certificate etc. His parents own a very small business and they cannot provide formal official income proof such as tax paper etc. He learned that the application would not be approved if his parents could not provide the required documents.

He said that Super Visa was only choice in that situation and not because his mother could stay longer in Canada. He added that even if his parents could provide the documents, it was too difficult and inconvenient for them to prepare the documents because his parents did not have much education. For him, Super Visa requires much fewer documents from parents than regular visa, and only focuses on the financial situation of immigrant children's side, which is the most important reason that he chooses to apply for a Super Visa. 
One participating family has applied for visas for parents of both sides. They applied for a regular visa for wife's parents, and a Super Visa for the husband's mother (she was divorced). The main reason is that the wife's parents have their own business in a big city and have very good financial situation, while the husband's mother lives in a small town and her financial situation is not good.

Other three participants choose Super Visa for the same main reason: Super Visa is convenient and fast. They all state that the regular visa requires too many documents from parents and too complicated for parents to prepare, and Super Visa is much easier to be approved thus their parents can come to Canada fast. All of them also mention that another consideration is the 2-years, because they want their parents to stay longer if they would like. It's interesting that these three participants all are very well settled in Canada, and their parents all live in big cities and have very good financial situation. No matter they apply for a regular visa or Super Visa, both applications will be approved.

2) Experiences of Application

Several participants noted that the application process was complicated and troublesome, especially to their parents.

\section{A. Medical Examination}

Medical examination is a mandatory requirement for Super Visa applicant. One participant feels that the medical examination is a big challenge for his mother. His mother lives in a small town and there is no IRCC designated physicians close to the city where she lives. His mother had to travel far away to a big city in another province to take medical examination. She took the train and traveled over night to get there, and had to stay in a hotel. In addition, his mother had pneumonia when she was young and there was a "shadow" in her lung, and she was asked to come back for two additional medical 
examinations. Every time, his mother had to take the train and stay in the hotel, thus not only was exhausted, but had to pay a lot of extra expenses.

The only parent participant I interviewed in person also mentioned the difficulty of medical examination. She lived in a smaller city and it took her more than one hour to go to the big city by bus for the medical examination. She noted that she has motion sickness and had to ask her husband to accompany her to take the medical examination. Her appointment with the doctor was in the morning and because she did not feel very well after the travel, she had to do the examination again in the afternoon.

\section{B. Documents and/or Information}

Almost every participant mentioned that some documents and/or information from parents' side are not necessary and should not be requested.

One participant said that the biggest challenge for him was the Education and Employment Form and the Family Form (IMM5645 form) which is the specific requirement for Chinese applicants. He stated that parents were old and they could not remember what they were doing in which year and which month, especially in 1960s in China. In addition, parents had to provide the home addresses and the occupations of all their siblings. His mother-in-law has five (5) siblings, and she had to call all the siblings to ask them for the information. This participant just cannot understand why government asks this kind of information because, he said that, "I am applying for a Super Visa for my parents, not their siblings, what it is for to ask their siblings' home addresses and occupations? It just does not make sense. It is too troublesome!" His wife agrees with him. She stated that her parents had to go to their workplaces to request a letter in order to prove their marital relationship. It took them a long time to get the required documents because they retired already and the company they had worked did not exist anymore. In 
addition, her mother had to go to the police station to check the information of her grandparents (mother's parents), and had to call her relatives to ask for their home addresses. She thinks that this is really troublesome for her parents and the information of her mother's relatives is not necessary for a visitor visa application.

Another participant expressed the same opinion. He applied for a Super Visa for his mother. His mother lives in a big southern city and all of his mother's siblings live in very small remote northern villages. He said that his mother had not visited her family for so many years and she just had no idea where her siblings were living. He added that, even she knew, the home addresses in a very small village could not be verified, thus would not make sense to IRCC. He cannot understand why government asks these kinds of information because "the application is only a visa application".

In addition, he mentioned that parents were old and it was really a trouble for them to do the copying, printing and scanning. "It is too troublesome. These things will kill them, really will kill them!" The time difference between Canada and China also adds more difficulty for children to help and guide parents to prepare required documents and information. This participant also emphasized that government should reduce the documents and information from the parents' side. He said that "Since I am sponsoring my parents for a Super Visa, it is no problem whatever documents and information the government asks from me...but needs to simplify procedure from parents' side."

The only parent participant I interviewed in person also stated the same problem. Her parents had passed away for many years. In order to provide the exact birth dates and death dates of her parents, she had to travel to the police station where her parents' household registration was with to check the information. She also highlighted another incident that showed the complexity. Before mailing their application, her husband went 
to a local bank to pay the government application fees, and her husband did not know that the bank had deducted RMB $¥ 15$ for handling the payment from the fees he paid, so the application was returned from the embassy because they failed to pay enough application fees. They had to pay the balance and mail the application again. This incident delayed the application for almost one month.

Another participant mentioned the troubles when he was preparing his own documents. He needed to provide his Birth Certificate or Household Book in order to prove his relationship with his parents as per the requirement. However, when he applied for immigration and before landing in Canada 16 years ago, he cancelled his household registration in China in order to get his Chinese passport. At that time, cancelation of household registration was a prerequisite to get a passport for Chinese who wanted to immigrate to other countries.

Another problem is that he lost his Birth Certificate and its notarization, and it took him more than one year to find someone who could help to make a new household registration book for his parents and put his name in it. He said that "It was a big trouble" Same with the discussion on "Reasons for applying for Super Visa for parent (s)", the three participants whose parents live in big cities feel that their applications do not encounter big issues, and the application process can be described as being smooth. One of them only mentioned that his mother had five siblings, and in order to confirm their information, his mother had to call them one by one. He also thinks that there is no meaning to request his grandparents' information because they have passed away for so many years.

One of them mentioned that, although the application process was quite smooth, there was an episode in the middle of the application. Only one week after her mother 
submitted the Super Visa application, her mother's passport was mailed back. Both her mother and she thought that this should mean that the application was approved because her family met the income requirement and there was no refusal letter was mailed with the passport. The whole family was so happy that the application was approved much faster than they had expected. So, she booked and bought the airplane ticket for her mother in a hurry. However, when arrived at the airport, her mother was told that there was no visa in her passport and she was not allowed to board the plane. The airplane company also refused to refund the payment of the ticket.

So, she wrote a letter to the Canadian embassy to ask what was going on with their application. The embassy admitted that there was a mistake. The officer forgot to put the visa in her mother's passport. The embassy apologized, but could not help them to get the refund of the ticket payment. The officer asked her mother to mail back her passport to the embassy, and after one week, the application was approved. This time her mother checked the passport and took a picture of the visa and sent to her. After confirmed that the visa was there, she booked the airplane ticket for her mother again. She told me that the money was not a big deal to their family, but her mother, who is 78 years old now, was much tossed due to the episode.

In summary, for the participants, the main challenges or difficulties of their application process are: firstly, there are no designated physicians close to their homes and they have to travel far away to take medical examination and extra expenses such as transportation, hotel may also incur. Secondly, some information or documents required from parents' side are too difficult to get, and information regarding their siblings and deceased parents are not necessary. Thirdly, generally speaking, the application requirements and procedure are too complicated for the parent (s) considering their age, 
education level, physical condition and other specific situations. Much simpler application design for the parents' side is highly suggested and requested.

3) Discussion regarding the three specific requirements for a Super Visa

Different with regular visa, Super Visa has three specific requirements: the children/grandchildren who will sponsor parents/grandparents to visit them must meet a minimum income requirement (Refer to the Appendix 1); the children/grandchildren must purchase $\$ 100,000$ private medical insurance coverage for at least one year for their parents/ grandparents; the parents/grandparents who will come to Canada on a Super Visa must take medical examination.

\section{A. Minimum Income Requirement}

With regard to the income requirement, the participants have three different opinions: Some think that there should be no minimum income requirement; some think that the minimum income requirement is necessary but should not be too high or should be more flexible; some think that the minimum income requirement is necessary and the amount is reasonable and acceptable.

One participant clearly expressed that there should be no income requirement. She argued that "those with low incomes need more help from their parents. If their parents can come to help them to take care of kids, they will have more time to work." She regarded the income requirement as a kind of discrimination. In her opinion:

...it is inhumane that they cannot apply for a Super Visa for parents only

because their income is low. It is inhumane and unacceptable to divide people by income. Everyone's situation is different. Those with higher education may have higher income, but those with lower education, such as laborers, they work hard and the jobs they are doing are also needed by 
Canada. Without them, how can Canada be so clean and beautiful? If everyone does professional job, who do the jobs with low salary? In fact, those who do jobs with low salary are more toiling, and work more hours. They must feel sad and more unbalanced if they are treated differently. To them, their parents are also parents; they are also children of their parents...

She states that her husband is an experienced real estate agent and they are very well settled now, but some of her friends have to work day and night in order to meet the income requirement for a Super Visa.

Her husband has different opinion. He thinks that there should have income requirement, but the requirement should not be too high. He agrees with his wife that those with low income also contribute to Canada and their parents also should be allowed to come to Canada to visit them. However, in his opinion, government should consider the whole Canadian society and a threshold should be set for the application of Super Visa: applicants should have ability to support themselves and their parents after they come to Canada. He pointed out that the income should be required to be higher than minimum wage; but if the parents have very good financial situation and can bring money with them to Canada for their stay, the income requirement of the children should be set lower and more flexible. Several other participants resonate with his opinion that the minimum income requirement is necessary for the interest of general public in Canada, but the requirement should not be too high.

Another participant argued that:

... In my opinion, if I have a stable income, I own a house that I can let my parents stay, then the requirement of income to me should not be that 
high. Actually, my parents came this time, they bought money themselves and they even gave me money.

In her opinion, the income requirement should be more flexible, and parents' financial situation should be considered.

Another participant has similar opinion but different arguments. He feels that the income requirement is acceptable for him because he has worked for several years, but the requirement to newcomers and new graduates should be reduced and more flexible. He argues that Canada is a multicultural society and welcomes immigrants, so it should not set barriers to block their parents coming in. According to his own experience, he hopes that some situations be given specific consideration. For example, he was seriously ill last year; if he had been a new graduate, his income could not have met the requirement, then there would be no way for his mother to come to Canada to take care of him. So he suggests that some special situations, such as sickness, should be given specific consideration. In addition, the income requirement for newcomers and new graduates also should be set to a lower level.

It is interesting that four participants strongly support the income requirement and believe that the requirement is necessary. One participant thinks that Super Visa is very humane. The income requirement is acceptable and is not high. She argues that: ...it is your problem that you have low income. You should try your best to adapt to society, rather than to ask the society to adapt to you. ... The requirement is a minimum already. When invite parents to Canada, children should have consideration for their parents. If your income is not good enough to afford your own life, then how can you support their lives when they come? It is because that no government would like the 
foreigners to be a burden on it. Every immigrant child is adult, you should take responsibility. Only if you have the ability to sponsor your parents to come to visit you, you should do it. If you cannot meet the minimum income requirement, it only demonstrates that you do not have the ability. Another participant expresses the similar consideration. He argues that: ... according to our experience, if my financial situation is not good, when my income is low and my life is not in good condition, it may not be a good thing to let parents to come to Canada. Nowadays, China develops very well. Our parents' life is good in China. If our life in Canada is bad, they will feel bad and very sad. They will wonder why you immigrate to Canada...

He does not think that the income requirement is discrimination. He explains that: ...I do not support Trump, but immigration and granting a visa is not a right but privilege. Now that it is a privilege, setting an income requirement is acceptable, although it may be not reasonable. Now that Super Visa is different from regular visa, it should be treated differently. Just like our experience, we applied for the regular visa and all were refused, while we applied for the Super Visa, we were approved. So, I do not object the requirements for a Super Visa, but the government must clearly tell me what exactly the requirement is, then I can accept it...

In his opinion, it would be not reasonable if the government required a $\$ 100,000$ income, but using “Low Income Cut-Off” is acceptable.

Another participant does not think that the income requirement is discrimination, either. He argues that Super Vis is through children's sponsorship. It only requires that children meet the requirement, and parents can come no matter the situation of their side is. In his opinion: 
...It is reasonable to have income requirement because if you even cannot support yourself, family from outside will be a burden on the Canadian society and they may do things they should not do. If want your parents to come, you must meet the income requirement, otherwise, you should go back to visit them.

Another participant also feels that the income requirement is not an issue to him and he thinks that to have an income requirement is to consider the interest of the whole Canadian society. In his opinion, if immigrant children's income is low and parents are invited to come, they may become a burden on children and the society.

\section{B. Purchasing Private Medical Insurance}

All participants believe that it is necessary to purchase private medical insurance for their elderly parents although most of them complain that the insurance is too expensive. One participant told me two stories. One is story of his wife's friend. The friend lives in London, Ontario. Father of the friend suddenly got myocardial infarction and died only one week after came to Canada. The friend said that they were lucky that they bought the private medical insurance for his father and the insurance covered most of the expenses. Another friend of them bought insurance when his parent came first time and nothing happened, so when the parent came again second time they did not purchase the insurance. Unfortunately, something wrong with the parent's heart this time, and they had to send the parent back to China to be treated in a hurry. He concluded that "so, it is very necessary to purchase insurance." Even when he applied for regular visa rather than Super Visa for his parents, he bought the insurance for them although purchasing private medical insurance is not mandatory for applying for a regular visa. While confirms the 
necessity of purchasing insurance, he points out that the required $\$ 100,000$ insured amount is too much, and the mandatory one year term is too long. He explains that: ...The insured amount does not need to be $\$ 100,000$, because nobody wishes to have to use the insurance, but it is necessary to buy insurance. We buy the peace of mind. However, once some bad thing happens, parents will go back to China. I have seen quite a few cases. As long as they are able to go back, all of them go back. So, they will not spend $\$ 100,000$. Everybody knows that it is much more expensive to see doctor in Canada than in China, so if they are able to return to China to see doctor, they definitely will go back.

He thinks that $\$ 50,000$ insured amount is good enough, and half year term is more reasonable because most parents only have stayed in Canada less than one year according to his experience.

Another participant also thinks that purchasing insurance is necessary, but the one year mandatory term may cause some issues. For him:

...The insurance regularly will cost at least around \$2000, and if parent's age is older, the cost will be much more. If it is not urgent matter, I guess, $70 \%$ to $80 \%$ families may decide not coming to Canada due to the expensive insurance cost. The insurance cost is not a small burden. In his opinion, the "insured term" should not be set to a fixed one year, but rather be more flexible. For example, the term can be given three options: below three months, six months to one year, and above one year. If parent will stay for only one month, then the family can choose the shortest term. For him, it is not reasonable to expect to buy one year insurance if parents stay only one week. 
Even if the insurance company will refund the payment, he still does not think it is reasonable because he has to pay the premium upfront. That payment is not a small amount and will be a big burden on most families.

Another participant also confirms that purchasing insurance is necessary and thinks that insurance is a safeguard if bad thing happens. He thinks if the premium is \$1000-\$2000 per year, averagely several bucks per day, he can accept it. On the other hand, he points out that after all, insurance is a burden. He suggests that premium should not be paid for the whole one year, but rather by quarter, or half-year like property tax. If possible, half-year term is more reasonable than 1-year.

Another participant also thinks that half year term is more reasonable. For him: ...If having options, it is better. I think 3-month term is too short, 6-month is reasonable. If having options such as 6 months, 9 months and 12 months, we can choose, it is better. Because, if you purchased 12-month, but only stayed for half year, you will not be refunded with half of the payment but proportionally returned, and you have to pay upfront. Refund is complicated. Purchasing according to the time you stay and having options is better. After all, several thousand dollars are not a small amount for each family.

He stresses that insurance must be purchased.

...The insurance premium of each of my parents is more than $\$ 3000$, and with their getting older, the premium will be more. From the viewpoint of my parents, they feel that they add the burden on us, but from my brother's and my point of view, we think that we must buy insurance 
because it is not only good for them, but also gives us peace of mind.

Insurance is very necessary.

Another two participants, who are wife and husband, both think that purchasing insurance is necessary, but have different opinions. The husband thinks that insurance purchasing should be mandatory to some parents. For example, parents in their 40s are not required to buy; 50-60-years-old can choose; and those above 60 years old must buy. The wife thinks that insurance is necessary, but should not be required to buy one year at a time. It should be more flexible. For example, purchase three months, or six months, and if parent wants to stay longer, then insurance can be renewed.

Another Couple-Participant also thinks that the requirement should make some changes. Both of them think that the insurance is necessary, but too expensive. The husband comments that:

...purchasing insurance is very necessary because it is too expensive to see doctor in Canada. Once something serious happened, whole family will be bankrupt. We buy a peace of mind. No matter regular visa or Super Visa, we will buy insurance. The problem is that the premium is too expensive...Two parents, insurance premium is $\$ 4000-\$ 5000$, how many families can afford? After paying the tax and mortgage, not much is left. To solve the problem, the wife suggests that the premium can be deducted month by month just like life insurance she has bought; or pay three months' premium deposit when sign the one year contract with the insurance company, and then the premium is deducted month by month. If it cannot be done in this way, she feels that purchasing three months or six months rather than one year is acceptable. 
For me, what is unexpected is that one participant feels that the insurance is acceptable and affordable. She explains that:

...my mother has mild diabetes. The insurance is $\$ 11$ per day, so it is affordable. Purchasing insurance not only is to safeguard parent, it is also responsible for us as children because once something wrong, the burden will fall on the whole family. Even if the government does not require purchasing insurance, we will pay to buy peace of mind.

In her opinion, insurance is necessary because it will be a big expense if something wrong with the health of senior parents. Insurance can reduce stress and worries. So, she believes that "purchasing insurance is for yourself; it is not doing extra for government. It is actually only a safeguard for you and your parents." When I asked her how to improve this requirement, she suggested that insurance term could be more flexible; it should be better to purchase the insurance according to the period of time parent will stay.

In summary, all the participants believe that purchasing private medical insurance for parents is very necessary. Most participants think that the premium is too expensive and is a burden, even a big burden on the family. All participants favour that the mandatory term should be shorter than one year. Some believe that the $\$ 100,000$ insurance amount is too much and should be changed to $\$ 50,000$ or less; and all suggest that the term be more flexible according to the time of parent's stay. Some suggest that the payment method also should be more flexible.

C. Taking Medical Examination

Most participants think that medical examination is necessary. According to one participant, “It is necessary. It only costs RMB ¥ 1300-1500. Taking the examination is to take responsibility for yourself. Before the travel, you need to know your own physical 
condition and to confirm that your health has no big issue." Another participant has similar stand. For him:

...Although it is troublesome, it is necessary. After all, parents are old.

Once something happens, there is no free medical treatment in Canada for them. Taking medical examination not only is good to them, but also to their children...If parent can pass the examination, it is good to all of us, as well as to government. As children, we can get peace of mind...

Only two participants do not think that medical examination is necessary. They are wife and husband. The husband argued that "Not necessary at all. We are required to purchase insurance, and we need to pay for the medicine and take care of parents' health. If there is any health issue, parents will not even board the airplane." They also said that they could not understand why Super Visa requires for medical examination while regular visa does not. They argued that:

...if there is serious health problem, what is the different between six months and two years? If parent has infectious disease, no matter six months' or two years' stay, the disease will be transferred to others. No mention six months, even several weeks or days, it will be transferred. If regular visa does not require medical examination, it is not necessary to require Super Visa applicant to take medical examination...

Another two participants who are also couples have similar thoughts. The husband admits that medical examination is necessary because it is good to the whole Canadian society, but he questions why applying for a regular visa does not need take medical examination. Both wife and husband think that the difference requirements do not make sense because the infectious disease is transferable no matter staying for six 
months or two years. One participant thinks that parent with cancer or other diseases such as diabetes should be allowed to enter Canada if the disease can be controlled and is stable.

In summary, most participants believe that medical examination is necessary because it is not only good for the public safety, but also good for the peace of mind of parents and children. Several participants question the different requirement between Super Visa and regular visa in this regard.

\section{4) Super Visa or Regular Multiple-Entry Visa?}

After discussed the three specific requirements for Super Visa, I asked the participants a question: now that regular multiple-entry visa can be valid for up-to 10 years which is same with Super Visa, the only difference is that Super Visa allows the parents/grandparents staying in Canada for up to two years each entry. In fact, most parents will not stay as long as two years. While the regular visa only allows them staying in Canada for six months, Super Visa has the extra three requirements. Now, let you to choose, will you apply for a Super Visa or regular visa for your parents?

Most participants answered that they would still choose Super Visa. One participant prefers Super Visa because Super Visa gives him more options. He explained that:

...what if parents want to stay for one year or my family has some changes, for example, one more child is born. You cannot control what will happen. Considering these situations, I feel Super Visa is better. It is more flexible and gives you more options. I will choose Super Visa although I have to purchase insurance and my parents have to take medical examination. In addition, when parents reach certain age, regular visa also requires 
medical examination. Now that both applications require passing medical examination, it's better to choose Super Visa than regular visa. If let me choose, I definitely choose Super Visa.

Another participant has similar opinion. She prefers Super Visa because the 2-year longer stay gives more freedom. If parents want to stay more than six months, they will not be forced to leave every six months.

For several other participants, choosing Super Visa rather than regular visa is because Super Visa is easier to be approved so parents are able to come to Canada fast. In addition, Super Visa allows parents to stay longer and no need many renewals.

Three participants expressed that choosing Super Visa was because they had no choice in their situation. In their opinion, the decision on applying for a Super Visa or regular visa depends on the applicants' specific situations.

The parent participant I interviewed told me that they applied for a regular visa for several times but all were refused. Due to the refusal, she could not come to Canada to take care of her daughter to give birth to both her grandson and granddaughter, which is called "Zuo Yue Zi" in China. So, she had to wait her daughter's family to meet the income requirement in order to apply for a Super Visa to come.

Similarly, for one participant, applying for a Super Visa is because the family's four applications for a regular visa were all refused. He states that "According to my situation today, I will choose 10 year multiple-entry regular visa, because my parents do not want to stay in Canada for long time. Our applying for a Super Visa for my motherin-law was forced. It was in order to bring her in." He adds that the decision making needs to consider all related factors. If parents want to stay longer, the Super Visa offers 
the flexibility. Financial consideration also is one factor. If there is no requirement of purchasing $\$ 100,000$ insurance but only $\$ 30,000$, he will apply for Super Visa.

Another participant has similar situation. He needed his parents to come to take care of him because he was very sick at that time. His parents could not provide some required documents for application for a regular visa, so he had no choice but to apply for a Super Visa for his mother. He said that "if we have met the requirements for both regular visa and Super Visa, in my current situation, if my parents will not stay for long time, I will apply for a regular visa because I do not need buy 1 year insurance.” But, he emphasized that:

...I think it should be decided case by case. Like me, I had to apply for a Super Visa for my mother, but if parents' financial condition is good, and there is no need to buy insurance, why apply for Super Visa? After all, you have to pay so much for insurance which really is a big burden... So for him, if regular visa works, there is no need to apply for a Super Visa due to the expensive insurance.

For one Couple-Participant, they applied for Super Visa for husband's mother because mother's financial situation was not good, but they have applied for regular visa for wife's parents because they have strong financial ability.

In summary, if meeting the requirements of both regular visa and Super Visa, majority of participants always prefer Super Visa mainly due to the flexibility or freedom of the 2-year-stay of their parents; or because it is easier to be approved and no need to be renewed after six months. For those who may choose regular visa, the main reason is the expensive insurance for a Super Visa, or parents will not stay for long time as well as they have good financial situation. 
5) Impact of parents' stay on immigrant children's life

A. Benefits and Challenges to Immigrant Children

Each and every participating immigrant child confirms that parent is helpful to their life. The main contributions of parents they mentioned are cooking for them, helping with household chores and taking care of their child or children.

However, the reasons why parents come to Canada are different. Some immigrant children need parents' help, such as taking care of their kids or themselves, even urgently sometimes; some want parents to come to see their life in Canada and enjoy the family time; some invite parents to come mainly due to worrying about elderly parents and hope they can spend more time with parents and take care of them.

A. The immigrant children need the help of their parents

One participant had been very sick last year. He is single and urgently need parents' help. Her mother came to Canada to take care of him on a Super Visa. He states that:

...when you are alone outside for so long time, it is a very sweet thing that there are family who can take care of you and accompany you... The benefits are obvious. I am offered very good three meals by mom. In addition, I have very good mood when she accompanies me and this is very helpful for my recovery. It is even more effective than medicine. If you have very good mood, your other conditions will also be greatly improved. In addition, my mom is very happy too because she can stay with me...I cannot use language to express how big her help to me that she can come this time... 
Parents of several participants come to take care of their daughters who just give birth; the first several months of this period is called "Zuo Yue Zi" in China, or they come to help to take care of their children's young kid(s), so their daughter can return to work.

One participant is the case. She first applied for a regular visa for her parents when she was pregnant in 2008, hoping her parents could take care of her "Zuo Yue Zi". However, all the four applications were refused. Then she applied for a Super Visa when she was pregnant again in 2013 and this time the application was approved. This participant feels that her mother is a great help to her life.

...Mother had been taking care of my second kid since she was born and till she was one year's old. My mother stayed for 1 year, so I returned to work. I had to quit my job because my mom went back. I only worked for two months. Later, she came again during the summer, and I returned to work again. Otherwise, I could not go to work. I took care of my second kid for the whole winter. It was until mom came again in the summer, I was able to work again...

Actually, for the second time, her mother did not want to come. For her parents, before came to Canada, they had worried about their life. That is the reason why they want to come to Canada. Now that they have already known what their life looks like in Canada, they are rest assured, so they do not want to come again. In addition, taking airplane makes them exhausted, and they cannot adapt to Canada's cold weather because they live in the warm southern part of China. Her mother had been sick for twice in Canada. The participant recalled that: 
...I had no idea how to make parents to come. I ask them to come to help me to take care of kids because I have to work. His (husband) mother called us and said that "we are too old to come". His father is almost 80 years old. His mother said to my mother that "you are younger" - my mother is in her 60s_ - "if you can help them, then please go to help them." That's why my mom agrees to come again reluctantly...

She explains that the daycare is too expensive. To afford the daycare, it needs high income; if salary is low, it is better to take care of kids by self.

Another participant who has two young kids expresses the same point of view “... at that time, daycare is $\$ 55$ per day, it is more than $\$ 1000$ a month which is almost equivalent to one person's salary." She states that she only can go to work after her mother comes, and she has felt much relaxed.

...I do not know much about how to cook. Two kids cannot eat well. After mom comes, she has always cooked many good foods. The meals are ready whenever we come home after work. Since mother is here, we do not need to worry about anything...

Another family also feels that parents can greatly help their life in Canada. It is husband's mother who has come on a Super Visa. The husband comments that "life becomes easier. I feel much relaxed”. The wife states that “... after my mother-in-law comes, she cooks and takes care of our kid, so the two of us can go out alone, not like before that we had to bring our daughter with us to anywhere." The husband adds that “...we cannot enjoy the world of only two of us because we have to bring our kid with us. We seldom have chance. We cannot go many places, such as pub, because my kid is too young to be allowed in. There are many restrictions..." 
For them, there are many benefits that their mother takes care of their daughter. Firstly, they feel more rest assured than sending their daughter to daycare. In daycare, one staff has to take care of many kids. The place in some daycare is very small. If one kid is sick, it is easier that all other kids get infected. In addition, there is no daycare during the night. Secondly, the cost of daycare is not a small amount. It is almost equal to the salary of one person, and if adding the expense of afterschool, it is hard to afford. Thirdly, the wife can work. The husband said that “... if my mother can take care of my kid, she (his wife) can go to work. I will be more relaxed if two of us pay mortgage together..."

Another participant did not have kid yet when her mother came, but still felt that her mother helped her a lot. She recalled that:

... at that time, we were operating a pub. We always went to home after midnight and got up very late next day. After got up, we ate some fast food in a hurry and then went to work again. After my mom came, she always prepared food for us and made it ready for us to eat anytime. She did cooking, laundry, and cleaned the house. During the half year she stayed with us, we did not need to do any housework...

Although all participants confirm the benefit or help from their parents, several participants clearly point out that the purpose for them to invite their parents to come is not to help them to take care of their children or they need other helps from parents.

One participant's mother is 78 years old now. She states that:

...I do not expect that she cooks for my family...the main thing is that her coming gives us the happiness of the three-generation-together (Tian Lun 
Zhi Le in Chinese). The key is the family affection. She is happy, I am happy and my kids are happy...

...I will not request elderly parent cook or take care of my kids. I do not want to give her burden...If she wants to cook, then, let her do it; it is totally okay if she does not want to do. Parents have no duty to take care of your kids or cook, no such duties...

Another participant has exactly the same opinion. He stated that " ...I do not want them to take care of my kid. Inviting them to come is just from the family affection. Let them to see my kid and enjoy the three-generation-together."

One participant's consideration is to have more time to stay with his elderly parents. He explains that:

...After all we have been grown adults and hope to stay with parents for more time. It is out of reality that we move back to China. We have jobs or own business. For me, I landed in 2006, and only went back for twice. I went back to attend my brother's wedding in 2007 and went back in 2015. Only this two times, and I have no time to accompany my parents. They are getting older and in the status of retirement. They have a lot of time, so it is a better choice for them to come...For me, asking them to come is not for the purpose of taking care of my kids, but rather that I can take care of them, which is out of filial piety. I can accompany them for more time. They are old now, how long can they stay in this world? ... It is interesting that one participant feels that parents are very helpful to her life on one hand; on the other hand, she feels a lot of pressure from her parents. She stated that: 
...Actually, when they come, I feel many pressures. They can help with my daily life; I do not need worry about anything about my household chores - they cook, clean the house, and wash the car for me-I do not need do anything; but I have a very busy job. After they come, I always stay at home on weekend and try my best to accompany them for more time; I cannot do anything for myself...

She told me that she felt great pressure from her parents to have a baby as soon as possible.

...They want me to have a child. I am 35 years old already. Actually, to have a baby is for their happiness. They say that if I do not have baby, they could not close their eyes when they die...I do not want to have a baby because I am so busy with my job...

In addition, her parents helped her for the down payment of her house and worry about that she may not afford for the mortgage by herself because she divorced recently, which also adds many pressure on her when she faces her parents.

Several participants mention that the difference of lifestyles between young people and old people is the concern of them. One participant states that he has already submitted the sponsoring immigration application for his parents, and they will buy an apartment for his parents to live which they both believe is better than living under one roof.

Another participant meets some challenges because he has different opinion with parents on the education of his kids. In addition, most participants mention that parents often feel boring and cannot go too far without their help due to the language barrier, not driving or the long winter of Canada. 
Generally speaking, although there are challenges or concerns, all the participants confirm that parents are helpful to their life and settlement in Canada not only by physical assistance but also through emotional connection and support, which all participants believe is more important to them.

B. Value of parents to Canada or only burden?

Popular discourse and policy makers regards elderly immigrant parents mainly as a burden on public welfare especially heath system according to the literature, so scholars critique that parents' contributions are greatly undervalued or even ignored. I asked several participants for their opinions.

One participant clearly states that he strongly disagrees the opinion that parents have no values to Canadian society and only are burden on Canada. He argues that: ...Firstly, Canada welcomes immigrants. Government cannot only accept those who are useful to you, and you cannot say that parents are useless to you. It is not the culture of Canada and it is not the public sentiment. Taking me for example, I get a degree in Canada; I work and pay tax. I contribute to Canada, right? People like me may be the prioritized immigrant candidates for Canada. But, we have our family life; we have parents; we have our own emotional and personal demands. Besides the monetary needs, we also have mental needs, which is very important. Those who work every day need somebody takes care of the family. I feel that parents take care of us and their contribution is not less than the dollar money generated through working.

He takes himself as an example and argues that if his parents could have taken care of him in Canada, he might not be sick, thus might not have to take leave and live on EI, and 
see doctors. He queries that “... why doesn’t government see the values generated by parents in these aspects? Government only considers that they cannot enter labour market, but their values cannot be assessed only by direct dollar amount..."

In addition, he points out that many families cannot afford for the daycare. Parents come to Canada to take care of young couple and their kids, parents' financial contribution per year to Canada, if transferred to dollar amount, actually cannot be said small at all! He questions that "how can you say that parents are only burden after they come to Canada and have no contribution?! It totally does not make sense! Very bad! I believe that many people have same viewpoint with me..." Moreover, he believes that it is also helpful to the stability of society if family is together and get along well with each other. Another participant expressed the similar opinion:

...How can it be said that parents are only burden? It is not the case. I have a friend whose mother had stayed for two years taking care of kids for her. Now her mother comes again, and has been doing volunteer job after the kids go to daycare. She does not ask even one cent, just do volunteer job. My friend is able to work only because her mother takes care of her kids, otherwise, her family's income will go down. Her mother helps her a lot but does not get any welfare...

Her husband added that "parents are old; their staying must have both pros and cons to Canada. It cannot be calculated only by direct monetary amount; the main value is family affection, it is emotionally."

In summary, all the participants do not agree that parents are only burden on them or Canadian society, and believe that their value should not be calculated only according to the contribution to labour market. 
C. Roles of your parent (s) in your children's education and inheritance of culture

Quite a few literatures have mentioned that grandparents play a big and crucial role in their immigrant grandchildren's mother tongue keeping, cultural inheritance and sense of belonging, so I discussed with some participants on this topic specifically.

Out of my expectation, all the participants do not think or have the expectation that their parents will or can play a big role in their kid's education or cultural inheritance.

For one participant, grandparents do not have big influence on grandchildren. Senior grandparents have difficulty to communicate with kids. She does not think that grandparents can help their grandchildren to learn Chinese. In the opinion of another participant, different generations have different education methods, concepts and views to the world, so they do not request much from parents on child's education.

One participant also has the same thought and points out that "...Educating kids is parents' responsibility; it is not the duty of grandmothers and grandfathers..." Another participant has the exactly same viewpoint which believes that it is the responsibility of parents to transfer ethnic culture to their children. He also thinks that " “...the role of grandparents also depends on the education level of the grandparents. Higher education level may be a little better, but I feel that most grandparents cannot play a big role; we do not have the expectation, either. We never want our parents to have this function." His wife agreed with him and added that:

...Grandparents definitely will bring something. For example, my father often tells stories of their life. My parents tell stories, but little kids cannot understand because they have not experienced those years and historical periods. They feel funny of those Chinese things. My parents also ask my kids to learn Chinese so my kids can talk with them when go to China in 
the future...My parents do bring something to my kids, but we do not request them to have this function. They can tell and let my kids to know some things when I was a kid, but we do not request them instill something to my kids. It is good enough to let my kids to have an impression to China and know what my life was like when I was in China. That's it...

Another participant also thinks that if grandparents have high level of education, they may play a role in cultural inheritance. However, in his opinion, most grandparents cannot play such a role. His argument is that "...time is different. Their time is already totally different from us, no mention from my kid. It is impossible for them to instill something to third generation." His wife believes that "the education from grandparents is mainly filial piety. To let kids get along well with seniors, and respect seniors. Respect the old and love the young." With regard to the Chinese language learning, she comments that:

...Teaching Chinese, it mainly depends on your own. You speak Chinese to your kids and tell them they are Chinese. If kids are forced to learn Chinese language, they will become offensive. I do not think that senior parents can play a big role in the language learning of kids; it requires the child's consciousness...

Different with all the above participants, one participant believes that whether or not senior parents can play a role in cultural heritage to third generation depending on how much weight the immigrant children put on it. Although he does not have a high request in this regard, in his opinion, some others do have this request because different people have different thoughts. He argues that: 
...some people may attach great importance to the inheritance of Chinese culture. No matter what, seniors have bigger strength than us in this regard because, firstly, we have education in Canada and many things have westernized; secondly, seniors are born and have been living in China, they have more understanding on Chinese culture than us. What we have learned are all from seniors. Therefore, if we emphasize cultural inheritance, parents can do more than us. For many traditions, we young people do not know or cannot do anymore, only old people know these things...

He concludes that it depends on what the request immigrant children have. ...If I do not hope that my kids are multicultural, or must know that they are Chinese, then cultural inheritance is not important to me. However, if you hope that kids are multicultural, and inherit the Chinese culture, then senior parents will play a role and even a bigger role, because you have to work, you have to integrate into local culture; you will have no energy to transfer these cultural heritage to your kids... and if you want to transfer, you must know it yourself first...many things... only seniors know. Young people cannot be competitive with seniors...

So, he believes that if immigrant children attach importance and at the same time their senior parents are good at it, then senior parents can play a big role in cultural inheritance.

There is one participant who does not think that senior parents can play an active role in child's education, on the contrary, their function may be counterproductive. In his opinion, the Western people have done better in this regard. He thinks that senior parents should not interfere with the education of grandchildren. Senior parents may give some 
advice generally, but should not interfere with details too much. Regarding the Chinese language learning, they have sent their kids to the Chinese School.

For all the participants, they do not expect or request their senior parents to educate their kids. The main role of senior parents can play is to take care of their kids rather than educate them. For most participants, having their senior parents to come is mainly for the purpose of enjoying the family time of three-generations-together. If there is an educational function, it will be letting their young kids to understand family affection and to learn filial piety.

6) Parents' experiences in Canada

Parents of most families that agree to participate are not in Canada currently. I only interviewed one parent face to face, and all other six parents have answered the interview questions in writing. Due to this situation, I could not ask further questions according to those parents' specific experiences in Canada, so while interviewing the immigrant children, I also asked them about how was their parents' stay in Canada.

A. Everyday life in Canada

While stayed in Canada, some of the parent participants had been very busy. The parent I interviewed in person has come to Canada twice. For the first time, she stayed for two and half year. She first stayed for two years on the Super Visa and then renewed the visa within Canada for another half year. Her daughter has two young kids, one is 7 years old and one is only 3 years old now. She comes to Canada to help her daughter to take care of the two young kids, so her daughter can return to work.

She told me that the first time when she came, the main activities for her were cooking, washing clothes and cleaning. At that time, her granddaughter was only six months, and one friend of her daughter who just gave birth also lived in her daughter's 
house then. So she had to taking care of two babies and two maternal women. She laughed that "...I cooked six to seven times a day, it's our tradition in Fujian for this period for women — it is called 'Zuo Yue Zi' — I had been spinning all day in the kitchen..."

The main purpose for her coming again this time is taking care of her daughter's two kids because her daughter needs go to work. Her main duty is sending her granddaughter to the Community Center close to home for a government supported program. All the kids and their parents or grandparents do activities or play games together there which are guided by a staff of the Community Center.

She brings her granddaughter to there every Monday to Thursday and they will stay there from 9:00 am to 12:00 pm and then go home. Before brings her granddaughter to the Community Center, she first needs to send her grandson to a Chinese School in the morning, then she goes back to have breakfast and takes her granddaughter to the Community Center. After returns from the Community Center, she prepares lunch for her granddaughter. After lunch, her granddaughter will sleep and she takes this time period to do cleaning. Then she prepares the dinner for the whole family. In addition, sometimes, she has to pick up her grandson around 6:00 pm if her daughter or son-in-law has no time.

She also mentions that her daughter's previous house has a big backyard, so she plants some vegetables. "I plant many, anything I want, such as broccoli, cabbage, tomato, spinach, just to reduce boredom and exercise my body..." I ask whether Chinese TV programs are available to her, she replies that "Yes, my son-in-law sets that for me. I watch TV at night and go to sleep around $11 \mathrm{pm}$ or $12 \mathrm{am}$. Sometimes I call to China. It has time difference, it is daytime in China. I chat with friends." 
What surprises me is that she becomes a volunteer in Canada. Every weekend, when her daughter and son-in-law can stay at home taking care of kids, she goes to Zhanshan Buddhist Temple to do volunteer job.

...I am very grateful for my son-in-law, he drives me to do volunteer job. If he had not supported me, I would not have been a volunteer. There are so many friends there. "You are from Fuqin, Fujian, Oh, we're fellowman", so we chat and I am so happy. I help for the cooking. We prepare foods for around 70 peoples. There are not only Chinese, but also people from other ethnicities. They also have this kind of faith. Much more people come when we have a congregation ceremony. I am so happy when I am there because time passes so fast. In addition, I go there also in order to remove my sins...

Other parents are not as busy as this parent participant, although some of them also take care of kids for their daughter or son, cook for the family and are in charge of household chores when they stay in Canada.

Some parents especially father parents, often feel that they have nothing to do and it is boring in Canada. The above mother parent participant whom I interviewed mentions that "... it snows in winter here, so we have to stay at home. Women are fine with it because we can do housework, but men cannot bear. My husband went back when winter came. There is no snow in our hometown, so he can go wherever he wants..."

One participating child does not have kid. She mentions that her father always feels boring if has nothing to do. Because felt too boring, her father had made a deck for her house. After being told that a deck could not be constructed without municipal approval in advance, he had to dismantle it. 
It is interesting that each and every immigrant child participant has mentioned that one of the biggest benefits they have received from parent(s) is that mother cooks for them. One participant mentions that "...my mother will come soon and my daughter is thrilled. For her, it means that she can eat delicious foods again..." Another child participant also states that:

...they cook for us, which solves a big problem for us because after all we have stayed in China for so long time before immigration, we still hope that we can eat foods with hometown's taste; we still like the meals that parents prepared for us. We feel so happy when eat the food that parents cooked for us...

He adds that:

...It is a way to take part in my life for parents to cook for my family. They also like cooking for us because they feel happy and rest assured when see that we can eat well and have strong bodies. They cannot stay here and do nothing. They must have things to do. Cooking is what they are able to do within their capacity, so they like to do it...

He also mentions that he lives in a Chinese community and his parents attend the activities such as playing cards, dancing etc. hosted by the community. "...there is one activity per week. My father likes to play Tai Chi, and sometimes they perform publicly. They are happy and like going there. The older they are, the more they act like a child. They like playing..."

Generally speaking, the main activities of everyday life of parents who are visiting children in Canada are taking care of their grandchildren, cooking, doing housework, gardening, walking around in the parks close to home, and physical 
exercising. In addition, one parent does volunteer job and one family's parents take part in activities hosted by Chinese community, which are not very common though.

B. What parents like and dislike Canada

All the parents like the summer of Canada. Several parents mention that people of Canada are friendly and everything is more in order than in China. The main challenges for them are language barrier, transportation, no friends, and feeling boring due to not many things that they can do. Several participants mention that it is hard for them to stay for the winter. Each and every immigrant child participant states that their parents like the fresh and clean air, and the blue sky of Canada. All the participating parents also mention that they like the natural environment of Canada.

To answer the question "what do you like Canada?" One participating parent puts that:

...Canada has a small population and is rich in resources. It has good air quality, more trees and green space; food is relatively clean and safe. It also has a better social order and people are more courteous. All these are the reasons that we like Canada, and what is more important for us is that our children are here...

Another participating parent also states that:

...Canada has vast land, fresh air, and lush vegetation. No matter urban or rural areas, broad city road or small village street, people being busy with work or housework, all are immersed in the sweet fragrance of flowers, which offers a happy and healthy feeling... In addition, Canada's policy on seniors is also much better than most countries in the world... 
With regard to the challenges for senior parents living in Canada, almost all the participants, both participating immigrant children and their parents state that language barrier and transportation are two big problems. One participating immigrant child states that:

...the first problem is language; second is that Canada has vast land and small population. In China, there is convenience store downstairs, and supermarket crossing the road; Here in Canada you must drive even buy a small goods.....My mom likes Canada but feels boring, no friends...She does not know anywhere. Wherever she goes, I have to accompany her. I am very busy, and if I cannot bring her out, she has to stay at home...

His wife adds that “...especially during winter, she cannot go anywhere. Language also is a problem...My mother-in-law likes Canada, but feels that it is not convenient, everywhere is English.” Another participant also points out all the issues:

...They do not get used to the lifestyle and weather here in Canada. After all, they have lived in China for so many years. They have no social life due to the language barrier and do not know the neighbours. Although they cannot adapt to all these issues, they still come to see us and help us. How great parents are!

One participating parent also mentions these challenges:

...Living in Canada is comfortable. Air and environment are good. Local people are very courteous and nice. The only problem is language barrier. Without being accompanied by my son, I have no way going out. I totally cannot communicate with others. In addition, all my relatives and friends 
are not here, it must have been very boring if it was not that my son has stayed at home with me due to his sickness...

The only participating parent I interviewed face to face told me that:

...When I first came, I could not adapt to it. Nowhere can I go. In China, neighbors know each other. I do not know anybody here. The good thing is that windows of my daughter's house are facing the street, so when I get up in the morning, I stand in front of the window and see people walk around in the street....My daughter and son-in-law are at home during weekends, so I have chance going out, otherwise, I feel that the time is so long...

She also mentions that:

...We cannot drive, when we want to go somewhere, we have to walk, and only can go somewhere nearby. In addition, my daughter is afraid that I may be lost. I did not have a cell phone at that time, and she was afraid that it would be troublesome if she could not find me... We cannot go out during the winter in Canada. My daughter does not let us out because she is afraid that we may slip and fall. If it snows, we only can stay at home... Another immigrant child participant mentions that his parents usually come in April and go back in October because the weather is good during this period. Same with his parents, parents of another participant only come during the summer now because they feel that the winter of Canada is too long and too cold, and the wind is too heavy. They cannot adapt to it as they have lived in a southern city in China which has warm winter. 
In summary, although parents like Canada, there are a lot of challenges that they have to face and adapt to.

7) Super Visa, Immigration and Family Reunification

A. Immigrate to Canada or Not?

After discuss the Pros and Cons of parents' stay in Canada, I ask the immigrant child participants that will they sponsor or have they sponsored parents to immigrate to Canada and the reason. Simultaneously, I asked the participating parents whether or not they want to live in Canada permanently with their children.

Some participants will sponsor their parents for immigration, and one participant has already submitted the sponsorship application and the application is still in processing. The participant who has already submitted the application states that:

...I submitted in 2016. The main reason is that my brother and I both are in Canada. In addition, I hope that parents can stay with us for more time while they are getting older. After all, nobody in China can take care of them, which is also the reason why I do not apply for the Canadian citizenship. Only I in my family do not apply for citizenship because if I do, I have to apply for a visa in order to go back China. I worry about that if something happens to my parents, I cannot go back in time. So, from this aspect, I hope that they can come to Canada, and if they can get permanent resident status, it does not need me to get back and forth. If they are here, it will be more convenient; it is better that they are able to stay in Canada... 
He emphasizes that the main reason that he sponsors the immigration of his parents is that, he hopes that his parents can stay longer with his and his brother's family when parents are getting older.

Another participant states that if he can meet the requirements, he will sponsor his mother. The reasons he gives are that:

...If have permanent status, you can come and go back anytime; no time limitation of stay, and there are many benefits which can safeguard your life. In addition, it is more convenient for you to travel to other countries with Canadian passport.

The participant, whose mother came to take care of him when he was sick, hopes that his parents can come permanently "because I will root here, as well as establish a family here, so I wish that my parents can come. To be frankly, Canada is quite suitable for the life of seniors, no matter social conditions and environment, it is better than China." But he adds that, the decision will depend on whether or not his parents would like to come. According to his understanding to his mother, if he needs help, his mother definitely will come; if everything is fine with him, his mother would more likely to stay at home in China. Actually, when answers the question, his mother puts that: ...wanting or not wanting to come, it is half and half. The only reason for coming is to take care of my child. His job is too busy; he has not paid attention to take care of himself. Home to him is just like a hotel. In addition, nobody cooks for him and cleans the house for him. He has no time to do these things. In particular, when he has child in the future, they will be too busy to take care of all things. 
Another participant also wants her parents to come. "It is better to apply for immigration, family should be together. What if they are too old to travel and I have no way going back? I am still worry about them..." However, she feels that it is not easy for the senior parents to immigrate to Canada. She thinks that the income requirement is too high for her to sponsor her parents.

It is interesting that she points out that if considering the health condition of her father who has cerebral thrombosis, she states that, she would rather not to apply for immigration for her parents.

...The doctors here in Canada do not have so many patients like in China, they do not have much experience... as well as that, the medical system is too slow in Canada. We have to wait for a very long time even for a simple medical check. If have disease like that of my father, how could you afford to wait such a long time? I cannot sacrifice my father's health and life in order for immigration. Several days ago, I mentioned about applying for immigration for them. My father said to me that "to be frankly, we do not have the thought to live with you permanently in Canada." If family needs to be together, they would rather I go back. It is mainly because my father's disease. It is too slow here in Canada to see doctors. Family doctor cannot diagnose the disease, and has to refer patient to specialist which takes too long time...

She complained that:

...Here in Canada, it will take half month to make an appointment with family doctor and half year to see a specialist, and only when you have urgent disease, the doctor can see you in time. If you have cancer, how can 
you afford to wait? Only considering the medical system, I will not let my parents come. I have a friend whose father died on the desk during the operation...In addition, language is also a problem, say, my mom knows the disease of my father, but how can she explain to the doctor here?... In the end, she repeated that she would not let her parents come if considering the medical system of Canada. It is out of my expectation that the reason prohibits the participant's immigration decision is the medical system of Canada, because, for me the medical system of Canada should have been an attractive factor for the immigration decision to Canada.

Several participants also mention that even they would like to sponsor their parents, the decision will depend on whether their parents want to come, the income requirement, the application processing time, their parent's age and health condition, as well as family's needs and other factors which may be related.

Five immigrant child participants and two parent participants clearly expressed that they would not sponsor their parents to immigrate or they would not like to immigrate to Canada.

One participant has met the income requirement, but she will not sponsor her mother to immigrate because her mother does not want to come. She mentioned two main reasons. One is that her mother does not stay long each time, and they think that Super Visa is good enough to allow her mother to come freely. Another reason is that if does not feel well, her mother would like go back to Shanghai to see doctor because here in Canada, the system is slow and will delay the treatment. She states that: ...Some parents are still young, and may want the pensions, but my mother has been almost 80 years old, and has no intention to immigrate. 
We asked her 5-6 years ago, and she said "why immigrate? It is good now that I want to come, then I come, and I want to go back, then I go back”... Another four participants are husband and wife from two families. For one family, the wife states that "my mother has passed away and there is no way to apply anymore. His (husband) parents are old, more than 70. They have their own life in China and get used to it already. We just apply for a Super Visa for them to come to see us and our kid, and enjoy the three-generations-together. He has brother and sister in China and can take care of them..."

The husband complains the long processing time and thinks that it has no meaning to apply for immigration when parents are already $70-80$ years old. He states that he does not have any intention to sponsor parents to immigrate Canada, and the main reason is that their parents are too old. He argues that even for young people, it is not easy to adapt to a new place where people speak different language. So he asks “...for those old people, who are already so old, and cannot understand the language, immigrating to Canada, what is it for?" When I asked him what his parents thought, he answered that "I will not ask my parents' opinion. I will make decision for the best interest of them."

For another family, both immigrant children and their participating parents do not have the plan for the immigration application. For the parents, they think that they have more freedom in China and their life there is easier, more convenient and colorful. "I do not want to immigrate to Canada. I live on a convenient street in China, and I have pension and medical insurance supported by the government. Most importantly, there are lots of activities that we can participate in China." 
For the immigrant children, the reason that they do not apply immigration for parents is mainly because the parents do not want to immigrate. Parents do not want to stay in Canada during the winter. For the husband, he has a brother in China and lives in the same city with parents. The life of his parents is good in China. However, the wife is the only child of her parents, and this is their only concern. They worry about that nobody can take care of the wife's parents in China when they get older or something happens. He also points out that:

...the "only child" issue is a concern and should be given consideration.

But it is troublesome if parents do not like to stay here, just like the story of the old lady I told you. She wants to go back and gives up the immigrant status. If they do not like here, we still sponsor them to immigrate, and force them to come, it is not good to them. Sponsoring them for immigration has pros and cons. If every family has siblings in China, like me, then it is not necessary to sponsor parents...

In summary, not all the families have intention to sponsor parents for immigration. For the families who will apply or have applied for immigration for parents, the main reason is that it is more convenient for the children to take care of their parents and enjoy the family time together. For those families that have no plan to sponsor, the main reason is that parents do not want to come and they enjoy life more in China.

Is Immigration for the welfare?

It is noteworthy that no participant who will sponsor or have sponsored the immigration of parent(s) states that the reason for their parents' immigration is due to the better welfare system of Canada. On the contrary, several participants mention that it is the concern on the issues or problems of Canada's medical system that discourages them 
to apply for the immigration for parents. In addition, most of them mention that it is more convenient to see doctor in China and once parents have disease, they will go back for the treatment.

This finding is totally different with the opinion held by the popular discourse, especially the think tank of the Federal Government. So I discussed more with regard to the topic of "immigration for the welfare" with the participants.

With regard to the discourse that believes that parents, especially those from the Global South, immigrating to Canada is for the welfare, one participant's response is that: ...It may be because that I come from a big city in China, I think that Canada should revaluate China. The medical system in China is not worse than that of Canada. I feel that the Canadian government should give a new look at and a new valuation to China... The change of China is so big..."

Taking his family as an example, he explains that:

...My parents' immigration is definitely not for the welfare. They have medical insurance and pension. Even if the pension is less than that of Canadian, the difference is not big. There is no any problem for their life, no mention that the price level is lower than that of Canada. Although it has been increased since recent years, the general price level is still low, so their life in China is not bad, and this is also the reason why they stay in Canada only half year during the summer. They feel China is better and more convenient. In addition, my parents have medical check each year no matter they come to Canada or not. The medical check is covered by the government supported medical insurance and is free. In addition, 
nowadays, seniors in China pay much attention to health care, and they are willing to spend money on this aspect. Where are health care products easy to be sold? It is in China! How many Canadian people buy health care products? So, some things have changed in China. I did not consider the medical welfare of Canada at all when I sponsored my parents for immigration. It may be one consideration when they get older and older, but definitely is not the main consideration for their immigration.

One participant totally disagrees with the popular discourse.

...What welfare? Who cares? My parents really do not care this; they just care me, their son. To be frankly, it does not matter having welfare or not. They have medical insurance welfare in China. They have all kinds of welfare. It is better for Canada to provide the welfare, otherwise, who will come? Parents may not come, they are afraid to be a burden on their children...

Another participant states that welfare can be one of the considerations, but definitely is not the main reason for the immigration of parents.

...My parents and my wife's parents all have medical insurance in China, and they like the medical treatment more in China. This is absolutely. I also believe that China's medical system is better to them and more convenient to them...

He also points out that welfare in Canada is also welfare, it is cannot be denied. In addition, he believes that Canada's medical condition is much better than that of China. He thinks that to make the decision, situation of both sides should be considered and compared. For his own case, he states that: 
...I think China's medical system is more convenient and safer to them. I never think that their immigration is for Canada's social and medical welfare. In China, they can get quicker medical treatment. In addition, there is language issue here. In China, they have doctors who are acquaintance and from social network, thus feel more convenient...

For his family, the only reason they may consider the immigration of parents is that his wife is the only child of her parents, and nobody in China can take care of them when they get older and sick.

B. Can Super Visa replace Immigration?

Although some participants will sponsor or have sponsored their parents to immigrate to Canada and some will not sponsor, except one immigrant child's parents answer that there is no difference to them because they do not want to immigrate to Canada, all the immigrant child participants and participating parents do not think that Super Visa can replace immigration.

One participant points out that the differences. For him, if parents become permanent residents, they can come to Canada anytime. There is no limitation on their stay, so they have more freedom, and they do not need to apply for a visa to come to Canada anymore. Moreover, he states that:

...they can buy their own house or cottage, so they can come or go back whenever they want. With Super Visa, they only can come when children invite them. They live in other's roof which is not their home after all, thus there is no sense of belonging..... The most important thing is the sense of belonging. No permanent status means no safeguard. You are not resident but only a visitor. This is not a place that you can stay long... 
His wife adds that "they also worry about that they may be a burden on children." Another participant expresses the similar opinion:

... Of course Super Visa cannot replace immigration. Firstly, parent is old people after all, if there is no immigrant status, he/she will not stay here at ease. He/she does not feel that he/she belongs here, so does not feel at ease staying here. Secondly, he/she will feel that he/she will be burden on his/her children, thus will not be able to stay long...

In the opinion of another participant,

...Super Visa cannot replace the immigration because Super Visa cannot grant welfares as immigration. Once parent has disease, and if the disease is serious, the private medical insurance will not cover all the cost. A friend's parent came here. Unfortunately, the parent got serious disease and needed operation. They couldn't afford the operation and had to send the parent back to China in a hurry...

Her husband has same opinion with her and thinks that Super Visa cannot be regarded as being equivalent to immigration because holders of Super Visa have no entitlement of pension and other social welfares. Same with him, another participant also thinks that Super Visa cannot replace immigration because Super Visa holders do not entitle medical welfare and have to buy expensive private medical insurance.

One participant stresses that:

...to have parents to come to Canada is not for the welfare and medical benefit, but rather for the sense of belonging which is more important. Not until mom and dad come, I really do not feel that my home is here, and my root is here. If I feel that my home is here, I will not want to go back to 
China, then, I feel that I do not have much difference with the local people here. My parents and I also being the master of this land, thus I feel that Canada is also a place that belongs to me; it is also my land, then I have the sense of belonging...

He states that there is no doubt that Super Visa cannot replace immigration. His arguments are that:

...the status under Super Visa is still a visitor; it is not immigrant after all.

You only can stay for maximum two years. What will happen after two years? You must leave...No matter senior parents or we as immigrants, each of us needs the sense of belonging...Parents come to Canada without formal immigrant status, they will always feel like outsiders. Not only parents, even us as immigrants, we also will feel like outsiders because our parents have no status. We feel that we are different from local people; not only them, but ourselves also feel we are different...

He also mentions that parents on Super Visa do not entitle medical warfare and they do not have family doctor in Canada. Once parents are sick, it is very troublesome because they need transcription and cannot buy medicine over the counter. "It is very inconvenient, and this is the big difference between the master and the guest..."

In summary, the main reasons participants believe that Super Visa cannot replace immigration are the sense of belongings, time limitation on stay and the freedom of moving between Canada and homeland, and the difference of entitlements of welfare especially medical benefits. Although no participant thinks that welfare is the main attraction for the immigration of parents, the possibility and privilege of getting medical 
and other social benefits is still a very important comfort and a safeguard for peace of mind for both immigrant children and their parents.

C. Family Reunification

So many literatures discuss family reunification and the immigration policy on family reunification. However, I do not find a clear or a standard definition for Family Reunification. Before I do this research, my assumption for Family Reunification is that parents come to live with their children together in Canada. However, I find that participants of my research have different understandings.

\section{What does Family Reunification mean to you?}

From discussions with participants, I find that, for most participants, Family Reunification does not mean that all family members live under one roof or parents and immigrant children live in one city. To most of them, Family Reunification means the freedom, flexibility or option available anytime for their parents to come to Canada and visit them. One participant states that:

In my opinion, Family Reunification is freedom, freedom to come to see me. If parents want to come, then they always can. They can come freely to see me; it is not that only staying together every day is Family Reunification...If urgent matter happens, parents can fly to Canada right away, or I can fly back to China, this kind of freedom is most important. If family wants to get together, then we always can, this is what we pursue...

He argues that population is always flowing in China and in many countries. Even when he was in China, he did not live in same city with his parents. But, when he wanted to go home, he could go right away and if parents want to see him, they also can come without any obstacle. He regards this freedom as the main meaning of Family Reunification. 
Another participant has similar thought. He points out that Family Reunification does not necessary mean that parents and children must live together under one roof. Even in China, he might not have lived together with his parents because they have different life style and networking, so conflict is unavoidable if live together for long time. So, for him, living together is not the main point for Family Reunification, but the availability and the option that is granted to parents to come Canada to see their children without any restriction or obstacle is the key for Family Reunification.

In the opinion of another participant, the concept of Family Reunification is mainly mentally rather than is physically. He argues that everyone is an independent individual and has different concepts and thoughts. In addition, when people get older, they have different habits. If there is habit conflict, it is not good for parents living together with their children.

His parents propose that once their immigration application is approved and they are landed Canada, they will not live in their children's house. The family has decided to buy a Condo for the parents to live. So, he concludes that:

...Family Reunification does not necessarily mean living together under one roof, but is mainly connected mentally. Keep separated space for both parents and children, at the same time, meet each other anytime when they want or need...thus, everyone can get peace of mind.

Based on the opinions of the participants, family reunification does not mean that family members live together under one roof, but the freedom for the family to be together without time limitation or other restrictions.

Does Super Visa help Family Reunification? 
Although there is complaint on the expensive insurance, difficulty in medical examination, and income requirement, all participants confirm that Super Visa can be easier approved, thus bring parents to Canada faster than regular visa. It is especially helpful for the family reunification of the families whose applications for a regular visa cannot be approved. Most participants clearly expressed that Super Visa is a good program and should be kept.

One participant, who was refused for four times for a regular visa application for his parents-in-law, states that:

...Super Visa is a very good program. It gives me certainty, I like it very much. I have my own business, I hope that government can reduce my cost, so it must give me certainty and should not confuse me like the regular visa requirement... Super Visa should be kept definitely. I support Super Visa $100 \%$, it is so good...

Another participant also thinks that Super Visa is very necessary “...At least I have this option. I cannot sponsor my parents for immigration currently, but with Super Visa, they still can come...they can stay for two years, it is also easy to be approved, I'd like to apply for Super Visa even if I have to buy insurance..."

In the opinion of another participant, ...So many people are applying for Super Visa which approves the necessity of it. Being there is reasonable. People need it and it has advantage, for example, it only requires immigrant children meet income requirement, not the parents, so like me, if there are issues in parent's side, regular visa application will be refused. This is what I need most from Super Visa and what I want to confirm it most. If there is no Super Visa, 
my parent would not have come when I was sick last year and no one would have taken care of me. I think it is very necessary to have Super Visa policy...

One participant not only regards Super Visa as a very good policy, but also argues for its insufficiency in facilitating family reunification comparing with immigration.

...I think Super Visa is already very humane, already a lenient policy... It is good enough already. In fact, to consider for government, is it real good to sponsor so many elderly parents to immigrate to Canada? It is in fact not good. From government's point of review, a country needs to keep its population young in order to generate more GDP. I do not mean that senior parents are burden, but sponsoring so many elderly parents to immigrate to Canada, it must add burden on the social, medical systems and public facilities. Of course, it is also not humane to let elderly parents to wait so many years to get family reunification through immigration, so it is very humane that Super Visa can let senior parents come fast for family reunification, and can stay for two years, and parents can come or leave whenever they want...

In summary, although Super Visa cannot replace immigration, all the participants think that Super Visa is helpful for facilitating family reunification.

8) How to improve Super Visa program?

While all the participants confirm that Super Visa is a good policy, especially comparing with regular visa, and all believe that it facilitates the family reunification, most of the participants also point out that Super Visa can be improved to better serve the immigrant families. 
Firstly, all of the participants think that the required documents and information from parents' side should be fewer and simpler, especially information of deceased parents and siblings are not necessary. Several participating immigrant children have mentioned that it is very difficult for their senior parents to get some documents or even do the simple copying, scanning and printing out, without the companion of young people or help from others. So, they suggest that the simpler the procedure for parent's side, the better.

Secondly, the specific three requirements for Super Visa should be more flexible. For the income requirement, some participants think that parents' financial situation also should be considered; if parents have strong financial capacity and they can afford their stay in Canada by themselves, the income requirement to immigrant children should be more flexible. Another suggestion is that some specific situations should be given special consideration, such as sickness and other urgent situations that immigrant children need parent's help. For these kinds of special situations, not only the income requirement to immigrant children should be more flexible, but also the processing should be expedited.

For the medical examination, parents of some participants have to travel far away to the big cities where there are designated physicians by IRCC. It is not only that parent feels exhausted, but also a lot of extra expenses such as hotel and transportation have incurred. Some participants wish that IRCC can grant authority to one or two big hospitals in every small city to do the medical examination.

For the private medical insurance, almost all the participants have mentioned that it is a big amount to a family, and even a burden on some families, although all the participants believe that it is very necessary to buy medical insurance for their parents. Some immigrant child participants express that they will buy the insurance even there is 
no such requirement, but almost all of them do not think that it is necessary to pay whole one-year lump sum, because parents usually stay less than one year each time. Some suggest that it is more reasonable if IRCC requires half year term rather than 1 year. Some suggest that applicants should be offered different options to choose according to the time their parents will stay.

In addition, some participants point out that, the processing of Super Visa should be a little faster. Although averagely two-months of the processing time is already much faster than that of immigration, sometimes, it is still cannot meet the needs of immigrant family especially in some urgent situation such as sickness. One participant points out that the processing time for a regular visa is around 1-2 weeks, why processing of Super Visa needs so much time?

Furthermore, all the participating immigrant children have pointed out that due to the language barrier and transportation, parents almost cannot go out for social life without their companion. This problem also is stated by each and every participating parent. One participating immigrant child suggests that government should offer opportunity of free language learning such as LINC to parents on Super Visa just like to those seniors who have immigrant status. Several other participants suggest more community activities for seniors including those seniors come to Canada on Super Visa.

Generally speaking, all participants, including both immigrant children and their participating parents, regard Super Visa as a good policy and wish the policy can be kept and improved to serve them better.

\section{CONCLUSIONS}

Through discussions with immigrant children and some of their participating parents about their experience of application for a Super Visa, and experience of parents' 
staying in Canada as well as the impact of their stay on immigrant children's life in Canada, the following conclusions can be reached:

Firstly, to immigrant children who have relatively high income-which has met the income requirement-Super Visa is a more effective way than regular visa for them to bring their parents to Canada. It has no financial requirement from parents' side and is easier to be approved than regular visa. In addition, it allows parents staying in Canada for up to two years each entry, thus provides bigger flexibility of the staying of parents, and can avoid the trouble of frequent renewals.

Super Visa is especially welcomed by the families whose applications for a regular visa are not successful, and those whose parents cannot meet the requirement or cannot provide the document for a regular visa. Among those families, some need their parent's help urgently such as taking care of giving birth or being sick.

With this finding, I cannot agree with some scholar who claims that Super Visa adds barriers on family reunification and blocks the opportunity for families especially those who direly need the help from their parents.

Secondly, the biggest attraction of Super Visa is not the "2-year" longer time of stay, which has been supposed and claimed by the government, but rather the easier and higher rate of approval than regular visa.

Except one parent had stayed in Canada for two years to take care of her daughter's new-born child while she came to Canada first time, no parent from other participating families have stayed more than 1 year. Most of the parents only have stayed half year or couple of months. All the participants state that what is more important to them is that Super Visa can bring parents to Canada when regular visa cannot, and can 
provide more flexibility for their parents to be able to come and leave; it is not the longer time that they can stay.

In addition, most of the parents do not want to stay in Canada for a long time due to the language barrier; lack of freedom of going out because most of them cannot drive; and lack of social life. They feel lonely and boring when their children cannot accompany them and have nothing to do. In addition, for quite a few of the parents who do not want to stay in Canada, the reason is that they cannot bear or adapt to the cold winter of Canada.

Thirdly, Super Visa cannot replace the immigration of parents because Super Visa is still a type of visitor visa. Although parents can choose to stay up to two years, they still have to leave before the time limitation expires. This temporary status cannot bestow the sense of belonging to parents, and to some immigrant children, they may also feel lack of the sense of belonging because their parents are treated as outsiders.

Difference in the entitlement of social warfare and benefits is also an important reason why participants do not think that Super Visa can replace immigration. With regard to Family Reunification, the main concern of the participants is that parents who come to Canada on Super Visa do not entitle of the medical benefits. Although the immigrant children have purchased the private medical insurance for their parents, if bad thing happens, and if parent is not able to go back to China for the treatment, they worry about that they may not afford the unexpected expenses. My study findings in this regard are similar with other scholars such as Bragg, Wong, etc. and confirm their conclusion that Super Visa cannot replace the immigration of parents and may not meet all the needs of family reunification. 
Fourthly, although participants have pointed out the difference between the Super Visa and immigration, and stated that Super Visa cannot replace immigration, no participants think that their parents' immigration to Canada is mainly for the welfare of Canada. Quite a few parents clearly express that they do not want to immigrate to Canada. For the parents who would like to immigrate to Canada, the main reason is that their child or children are there; their children need their help, or they want to stay with their children and their family to enjoy family time. For the immigrant children, the main reason is that their parents are getting older and older, and they want to stay with senior parents for more time, and let their senior parents to enjoy three-generations-together. In addition, it is easier and more convenient for them to take care of parents in Canada.

For most of the participants, it is more convenient for parents to have medical treatment in China. Some participants have complained the medical system of Canada and believe that China's medical system is better than that of Canada, no mention the language barrier for parents and themselves. One immigrant child participant also points out that there have been a lot of changes in China for recent years and Canada should take a new look at and revaluate some countries from the Global South, such as China.

These findings are quite different with the popular discourse and the opinion of policy makers, which claims that the main purpose that parents and grandparents from the Global South immigrate to Canada is to enjoy the much better welfare in Canada, thus they regard immigrant seniors as big burden on the social and medical system of Canada.

Fifthly, all the immigrant child participants do not think that parents are only burden on the Canada's welfare system. On the contrary, most of them claim that parents help them a lot especially those who have young kids. For some of the female participants, they only can return to work when their mothers come to Canada to take 
care of their kids. For some of the child participants, the emotional connection with and support from parents is more important to them and offers them peace of mind.

Some immigrant child participants point out that the value of parents should not be calculated only according to the direct contribution to labor market, and one participant argues that the value she contributes to the labour market should be regarded as her mother's contribution because she would not have returned to work if her mother had not come to Canada to help her taking care of her children.

My findings in this regard totally resonate with that of many other scholars who criticize the discourse that evaluating of parents' contributions is only based on the direct value they can add to the labour market. My study finding also supports the argument that parents' social and emotional value in supporting the settlement of their immigrant children is underestimated and even ignored by policy makers.

Sixthly, with regard to the roles of parents in third generation's education, all the child participants do not think that their parents can play a big role in their children's education, ethnic language learning and maintaining, and sense of belonging. Some participants even point out that parents' involvement may play a negative role due to the conflict of concepts and different viewpoints between different generations. It is a good example that a participant's daughter and her classmate said that they hate their grandparents.

All the participants believe that, if they need, the main help from their parents is taking care of their children such as cooking for them, playing with them, sending them to school and picking up them from school. In the opinions of most of my research participants, it is the responsibility of parents rather than grandparents to educate their children, and they do not have expectation from their senior parents in this regard. 
This finding is different with some researchers' opinion which claims that grandparents play an important role in immigrant grandchildren's language learning, cultural inheritance and sense of belonging. My research also does not find evidence that grandparents can facilitate immigrant grandchildren's construction of identity, although with a grandparent at home, they may have a sense of descent and origin, and feel the difference of cultures. The difference between my finding and findings of other scholars may because that the grandchildren in the participating families of my research are all very young (15 years old or younger), thus they lack of the strong sense of belonging, ethnic identity and cultural difference.

Seventhly, with regard to the specific requirements for the application for a Super Visa, most participants regard the income requirement as being necessary and acceptable, and do not think it is a kind of discrimination. For insurance, although most of the participants feel that the insurance is too expensive, all of them believe that purchasing private medical insurance is absolutely necessary, and some state that they definitely will buy even if there is no such requirement. Quite a few participants think that the income requirement and requirement of purchasing insurance are necessary because it is not only good to the government, but also for the benefit of the immigrant families.

This finding is different with some scholars' opinion which claims that the income requirement reinforces the racialization and furthers the cycle of poverty; and the prohibitive insurance cost blocks the opportunity of family reunification.

On the other hand, same with other researchers, my finding also finds that the insurance premium is a big amount for most of the participating families and even a burden on some families. It is highly requested to be revised to a more affordable amount for immigrant families. 
Eighthly, for the immigrant families, the meaning of "Family Reunification" is not that all the family members stay together under one roof or stay together every day, but rather it is a freedom or option available to the senior parents that they can come to Canada to visit their children whenever they want or need, and they can leave whenever they wish without any restriction.

In conclusion, generally speaking, Super Visa is a good policy for immigrant family firstly because it can help to facilitate family reunification, especially to those families who cannot get a regular visa for their parents; secondly, although it cannot replace PR status and may not meet all the needs of immigrant families, it allows longer stay, thus provides more flexibility for the immigrant families.

\section{RECOMMENDATIONS}

According to my study's findings, and to reflect participants' voices, I believe the following suggestions and matters should be considered by policy makers in the future:

\section{Super Visa}

1. Making the application process easier and simpler for parents I suggest that parents are requested fewer documents. Do not ask the parents provide their parents' and siblings' information and their education and employment history.

2. Shortening the term of private insurance

To make the private insurance more affordable, I suggest changing the requirement of purchasing one year private medical insurance for parent to half year, or offering different options according to the time of parent's planed stay.

3. Providing more flexible income requirement for immigrant children I suggest that the Federal Government considers more flexible income requirement for immigrant children who catch serious disease or have other urgent matters that need the 
help of their parents, and give expedited processing to their applications. In addition, requires less income for the immigrant children whose parents have strong financial ability and can afford their own stay in Canada.

4. Making the medical examination of parents more convenient and easier I suggest designating at least one local hospital in every small city in China, or recognize the medical report of local hospitals.

5. Shortening the processing time of Super Visa

Although the processing time is shorter than 7-8 years waiting time of immigration, comparing with regular visa, the two months processing time for Super Visa is still too long. Reducing to one month may be more reasonable.

\section{Other Related Matters}

1. Giving immigration priority to parents whose only child is in Canada

My study finds that the biggest concern of most immigrant children is that they cannot take care of or it is not convenient for them to take care of their senior parents when parents get older, especially for those who are the only child of their parents.

As per current immigration policy, to sponsor parents for their immigration, immigrant children will be randomly drawn from the application pool and have to wait for the invitation from IRCC if they are selected.

I suggest that the parents whose only child is in Canada be given priority and their children do not need to be drawn from the waiting pool. They can apply for immigration for their parents once meet all the requirements.

2. Providing more community services and activities for parents on Super Visa

My study finds that a big problem for the parents in Canada is that they lack of social life due to language barrier and transportation issues. Parents who have 
opportunity to attend activities hosted by ethnical community centers can help them a lot in this regard.

I recommend that community centers add specific services for senior parents on Super Visa and design activities which can accommodate their needs and period of stay.

3. Providing opportunity for free language training

Every participants of my study have mentioned that language barrier is a big problem for parents. I agree with couple of the participants who suggest that government should also provide free language training opportunities for those parents who would like to learn English.

I suggest that the main free language training agencies such as LINC, also open to parents who come to Canada on Super Visa.

4. Making it easier to see doctor for parents on Super Visa

Some participants mention that it is not convenient for parents to see doctor although they have purchased the private medical insurance for their parents. Parents on Super Visa do not have family doctors and they cannot buy medicine without the transcription of doctor. So, I agree with the suggestion from one participant to make children's family doctor available to parent on Super Visa.

In addition, several participants mention that their parents bring medicine with them from China and do not want to see doctors when they do not feel well. Research on the health condition of this specific group of seniors in Canada may be necessary.

5. Providing consultation services for family problems

One participant points out that more than half of the senior parents in Canada are not happy because of the family issues, no matter they have permanent resident status or come on visitor visa. He has been providing accounting services for the Chinese 
communities for a long time, and he gives me the number of $70 \%-80 \%$ according to his own experience.

I do not have opportunity yet to verify this number, but I believe that senior parents need help in this regard. I suggest that senior parents' mental health be given attention and more related services and researches are needed.

\section{LIMITATIONS}

Firstly, all the participants for my study are from Chinese community, so my findings and conclusions may not be applicable to other ethnical communities due to the cultural differences and/or the different social and economic conditions among China and other countries.

Secondly, all the participants for my study have met the income requirement - the low-income-cut-off, and thus have a successful application for a Super Visa, so my findings and conclusions are only based on this group. For the families with low income, who cannot meet the income requirement, their thoughts with regard to Super Visa may be totally different!

In addition, due to the time limitation, I do not recruit families who meet the income requirement and have applied for a Super Visa but are refused, so I do not know the reasons why they are refused and what their application experiences are, and what their opinions on Super Visa.

So, my findings and conclusions cannot represent the experiences and thoughts of immigrant families from different ethical communities. Due to the small sample population of my study, my findings and conclusions may not reflect all the typical experiences and viewpoints of immigrant families from Chinese community. 


\section{Appendices}

\section{A. Interview Questions}

\section{For adult immigrant 对成年子女的问题}

1. Demographic data such as: (1) When did you land in Canada? (2) How many years have you been in Canada? (3) How old are you and how many children do you have? (4) What do you do for a living?
有关的个人信息，比如:
（1）你什么时候移民加拿大的?
(2) 你在加拿大几年了? (3)
你多大年纪? 有几个孩子?
(4) 你做什么工作或你靠什么过活?

2. Why did you apply for a Super Visa for your parent or parents?

你为什么为你父/母申请超级签证啊?

3. Your experience of applying for a Super Visa. What was your experience with the application process? What challenges did you experience when you apply for a Super Visa?

请谈谈你的关于超级签证的经历。谈谈你的超级签证申请过程好吗？申请超级签证时你有 什么困难吗?

4. How does the Super Visa help your family or not help your family? How has your life changed before and after your parent (parents) come to Canada?

请谈谈超级签证是怎么帮助你的家庭或没有帮到你的家庭的？你父/母来到加拿大前和他们 来后你的生活发生了什么变化?

5. Did you ever apply for a regular visa for your parent (parents)? If yes, how was your experience with that process? How that experience is different with your experience of applying for a Super Visa?

你之前为你父/母申请过普通签证吗? 如果申请过, 谈谈你的经历好吗? 普通签证的申请经 历和申请超级签证的经历有什么不同吗?

6. Have you applied for immigration for your parent(s) under family sponsorship program? Why or why not?

你递交了担保父/母移民的申请了吗? 为什么申请? 为什么没申请?

7. What do you think how Super Visa program can better serve your family? 你认为超级签证项目怎样才可以更好的帮到你们家庭?

Additional questions for clarification may be asked depending on their answers to the above questions. 根据受访人对上述问题的回答, 为把问题回答清楚, 另外的问题可能被问到。 
For the elderly parent (or parents) 对老年父/母亲的问题

1. Demographic data: such as (1) How old are you? (2) Where are you from? (3) How many children do you have? How many of them are living in Canada? (4) Do you live with your other child in China? (5) Are you retired? If yes, what did you do before retirement?
有关的个人信息, 比如:
（1）您多大年纪了?
（2）您从哪儿来啊?
（3）您有几个孩子啊?
有几个孩子在加拿大啊?
（4）您在中国时和别的孩子住一起吗?
（4）您退休了吗? 退休 前做什么工作啊?

2. Why do you apply for a Super Visa to come to Canada? How is your experience for applying for the Super Visa?

您为什么申请超级签证来加拿大啊？谈谈您申请超级签证的经历好吗?

3. Please describe a typical day of your life in Canada: from getting up in the morning till going to sleep. What do you like and not like about your life in Canada?

请描述一下您在加拿大的一天通常是什么样子的：从早上起来直到晚上睡觉。 请谈谈您都喜欢你在加拿大生活的哪些方面, 不喜欢哪些方面?

4. How many times did you come to Canada? How long did you stay each time? Why did you leave Canada each time?

您来过加拿大几次了？每次来都呆多久? 每次都是因为什么原因离开加拿大?

5. Did you live with your child before he/she immigrated to Canada? How does your child's postmigration life affect your life?

您孩子移民前你们住一起吗? 您孩子移民后他们的生活变化对您的生活有什么影响吗?

6. Do you want to come to Canada and live with your child's family permanently? Why or why not? 您想来加拿大和您的孩子长期住在一起吗? 为什么呢?

7. What do you think about Super Visa? How does it help or not help with reunification with your child and grandchild?

您怎么看超级签证啊？您觉得超级签证能帮助您和您孩子和孙辈团聚吗？

Additional clarification questions may be asked depending on their answers to above questions.

根据受访人对上述问题的回答, 为把问题回答清楚, 另外的问题可能被问到。 
B. Income Table

Effective from January 1 to December 31, 2017

Your child or grandchild may use the following income scale to assess their ability to meet the income requirements.

Low Income Cut-Off (LICO)

Size of Family Unit

Minimum necessary income

1 person (your child or grandchild)

$\$ 24,600$

2 persons

$\$ 30,625$

3 persons

$\$ 37,650$

4 persons

$\$ 45,712$

5 persons

$\$ 51,846$

6 persons

$\$ 58,473$

7 persons

$\$ 65,101$

More than 7 persons, for each additional person, add

$\$ 6,628$

Source: IRCC

http://www.cic.gc.ca/english/information/applications/guides/5256ETOC.asp\#incometables 


\section{References}

Abu-Laban, Y. \& Gabriel, C. (2002). Selling Diversity: Immigration, Multiculturalism, Employment Equity and Globalization. Excerpt from Contemporary Directions: Immigration and Citizenship Policy 1993-2001 (pp. 86-97, 103-104). Broadview Press.

Arat-Koc, S. (1999). Neo-Liberalism, State Restructuring and Immigration: Changes in Canadian Policies in the 1990s. Journal of Canadian Studies, 34(2), 31-56.

Bragg, B., Ethno-Cultural Council of Calgary, \& Canadian Electronic Library (Firm). (2014). Families together/families apart: the social and economic impacts of family separation and the changes to the family reunification program in Canada. Retrieved from http://books.scholarsportal.info/viewdoc.html?id=678174

Bragg, B., and Wong, L. L. (2016). "Cancelled Dreams": Family Reunification and Shifting Canadian Immigration Policy. Journal of Immigrant \& Refugee Studies, 14(1), 46-65.

CIC. (2011). Backgrounder-Phase I of Action Plan for Faster Family Reunification.

Retrieved from

http://www.cic.gc.ca/english/department/media/backgrounders/2011/2011-1104.asp

CIC. (2011). Determine your eligibility-Visit your children or grandchildren. Retrieved from http://www.cic.gc.ca/english/visit/supervisa-who.asp

Collacott, M., Canadian Electronic Library (Firm), \& Fraser Institute (Vancouver, B.C.). (2014). Canadian family class immigration: the parent and grandparent component under review. Retrieved from http://books1.scholarsportal.info/viewdoc.html?id=/ebooks/ebooks0/gibson_cppc/ 2014-02-25/1/10813060

Ferrer, Ilyan. (2015). Examining the disjuncture between policy and care in Canada's Parent and Grandparent Supervisa. International Journal of Migration, Health and Social Care, 11 (4), 253-267

Gabriel, C. (2006). A Question of Skills: Gender, Migration Policy and the Global Political Economy. In K. V. D. Pijl, L. Assassi \& D. Wigen (Eds.) Global 
Regulation: Managing Crises After the Imperial Turn. (pp. 162-176). Palgrave Macmillan.

IRCC. (2016). Changes to application intake process for 2017 Parent and Grandparent Program. Retrieved from http://news.gc.ca/web/article-en.do?nid=1168899

Keung, N. (2011, December 31), Only ‘rich’ can afford super visa: $\$ 2,000-\$ 4,000$ cost of mandatory health premium deters parents from visiting immigrant children. Toronto Star. Retrieved from http://search.proquest.com.ezproxy.lib.ryerson.ca/docview/913141468?pqorigsite $=$ summon

Neborak, J., Ryerson Centre for Immigration and Settlement, \& Canadian Electronic Library (Firm). (2014). Family reunification?: a critical analysis of Citizenship and Immigration Canada's 2013 reforms to the Family Class. Retrieved from http://books.scholarsportal.info/viewdoc.html?id=641578

Siemiatychi, Myer. (2015). Continuity and change in Canadian immigration policy. In H.

Bauder \& J. Shields (Eds.), Immigrant Experiences in North America:

Understanding Settlement and Integration. (pp.93-117). Toronto: Canadian Scholars Press

Stephen, Vineeth. (2013). Indian diasporic grandparents in Canada and changing roles for grandparents across nations. In A. Singh (Ed.), Indian Diaspora (pp189-206). Retrieved from http://link.springer.com.ezproxy.lib.ryerson.ca/book/10.1007\%2F978-94-6209467-3

Zhou, Yanqiu Rachel. (2013). Toward transnational care interdependence: Rethinking the relationships between care, immigration and social policy. Global Social Policy, 13 (3), 280-298 